\title{
Regulated deficit irrigation for crop production under drought stress. A review
}

\author{
Qiang Chai ${ }^{1,3}$ - Yantai Gan ${ }^{2}$ Cai Zhao ${ }^{1,3} \cdot$ Hui-Lian $\mathrm{Xu}^{5}$ - Reagan M. Waskom ${ }^{4}$. \\ Yining Niu ${ }^{1,2} \cdot$ Kadambot H. M. Siddique ${ }^{6}$
}

Accepted: 6 November 2015 / Published online: 18 December 2015

(C) The Author(s) 2015. This article is published with open access at SpringerLink.com

\begin{abstract}
Agriculture consumes more than two thirds of the total freshwater of the planet. This issue causes substantial conflict in freshwater allocation between agriculture and other economic sectors. Regulated deficit irrigation (RDI) is key technology because it helps to improve water use efficiency. Nonetheless, there is a lack of understanding of the mechanisms with which plants respond to RDI. In particular, little is known about how RDI might increase crop production while reducing the amount of irrigation water in real-world agriculture. In this review, we found that RDI is largely implemented through three approaches: (1) growth stage-based deficit irrigation, (2) partial root-zone irrigation, and (3) subsurface dripper irrigation. Among these, partial root-zone irrigation is the most popular and effective because many field crops and some woody crops can save irrigation water up to 20 to $30 \%$
\end{abstract}

\footnotetext{
Qiang Chai

Chaiq@gsau.edu.cn

$\triangle$ Yantai Gan

Gan@agr.gc.ca
}

1 Gansu Provincial Key Laboratory for Aridland Crop Sciences, Gansu Agricultural University, Lanzhou 730070, Gansu, China

2 Agriculture and Agri-Food Canada, Swift Current Research and Development Centre, Saskatchewan S9H 3X2, Canada

3 College of Agronomy, Gansu Agricultural University, Lanzhou 730070, Gansu, China

4 Colorado Water Institute, Colorado State University, Fort Collins, CO 80523, USA

5 International Nature Farming Research Center, 5632-1 Hata, Matsumoto City, Nagano 390-1401, Japan

6 The UWA Institute of Agriculture, The University of Western Australia, 35 Stirling Highway, Crawley, WA 6009, Australia without or with a minimal impact on crop yield. Improved water use efficiency with RDI is mainly due to the following: (1) enhanced guard cell signal transduction network that decreases transpiration water loss, (2) optimized stomatal control that improves the photosynthesis to transpiration ratio, and (3) decreased evaporative surface areas with partial root-zone irrigation that reduces soil evaporation. The mechanisms involved in the plant response to RDI-induced water stress include the morphological traits, e.g., increased root to shoot ratio and improved nutrient uptake and recovery; physiological traits, e.g., stomatal closure, decreased leaf respiration, and maintained photosynthesis; and biochemical traits, e.g., increased signaling molecules and enhanced antioxidation enzymatic activity.

Keywords Agricultural water · Drought stress · Irrigation management $\cdot$ Leaf water potential $\cdot$ Partial root-zone drying . Stomatal conductance $\cdot$ Stress-tolerant mechanism $\cdot$ Water deficit

Contents

1. Introduction

2. Definition and main approaches

2.1. Stage-based deficit irrigation

2.2. Partial root-zone irrigation

2.3. Subsurface irrigation or infiltration movement

3. Physiological basis

3.1. Leaf water content

3.2. Stomatal morphology

3.3. Photosynthesis and respiration

4. Biochemical basis

4.1. Plant hormones

4.2. Antioxidation enzymes

4.3. Non-enzymatic substances 
5. Plant water status under regulated deficit irrigation

5.1. Determination of water use efficiency

5.2. Improvement of water use efficiency under regulated deficit irrigation

5.3. Mechanisms involved in improved water use efficiency

6. Agronomic practices for improving crop productivity under regulated deficit irrigation

6.1. Promoting plant growth and development

6.2. Stimulating root activity

6.3. Maintaining or increasing plant yield

6.4. Influencing product quality

6.5. Improving nutrient use efficiency

6.6. Enhancing plant acclimatization through biochemical approaches

7. Opportunities and challenges

7.1. Opportunities

7.2. Challenges

8. Suggestions for future research

8.1. Signaling systems

8.2. Physiological and biochemical responses

8.3. Quantification of the magnitude of deficits

8.4. Potential impacts on soil quality attributes

9. Conclusion

References

\section{Introduction}

About $70 \%$ of Earth's surface is covered by water (Küppers et al. 2014; Siddique and Bramley 2014), but only about $2.5 \%$ is freshwater (Gleick and Palaniappan 2010). The majority of water is trapped in glaciers, permanent snow, or aquifers (Farihi et al. 2013; Sivakumar 2011). Water shortages threaten many parts of the world, with nearly 800 million people lack access to safe drinking water and 2.5 billion have no proper sanitation (Schiermeier 2014). The situation may get worse in coming decades, as world's population is expected to increase by $30 \%$ by 2050 (Godfray et al. 2010) coupled with forecasted climate change (de Wit and Stankiewicz 2006). It is estimated that up to one fifth of the global population could suffer severe shortages of freshwater (Schiermeier 2014) or quality water in the foreseeable future (Girones et al. 2010).

Agriculture is the largest freshwater user on the planet, consuming more than two thirds of total withdrawals (Gan et al. 2013). In many parts of the world, irrigation water has been over-exploited and over-used (Chai et al. 2014a), and freshwater shortage is becoming critical in the arid and semiarid areas of the world (Forouzani and Karami 2011). For example, China has water resource that is about one quarter of the world's average per capita (Liu 2006). The country's availability of water resources has declined in recent years, fast approaching the internationally accepted threshold for water shortage of $1700 \mathrm{~m}^{3}$ per capita per year. China needs to produce various commodities to meet the needs of the fastgrowing economy and the 1.3 billion people's needs for food, feed, fiber, and fuel (Nie et al. 2012). Yet, the availability of freshwater for the country's economy is approaching zero to negative growth in the foreseeable future (Liu 2006). Also, rapid urbanization has caused conflict between the need for freshwater in agriculture and other sectors. Consequently, freshwater resources available to agriculture will need to be re-rationalized to satisfy the developmental needs of other sectors. In a recent review, regulated deficit irrigation (RDI) has been identified as one of the key water-saving technologies in agriculture (Chai et al. 2014a). However, there is a lack of detailed information on the definition, scientific principles, or specific practices of RDI. Little is known about how this technology may be practiced effectively in real-world agriculture.

In the present review, we focus on three aspects: (1) the definition of RDI and its main application in agriculture; (2) morphological, physiological, and biochemical basis of plant responses to RDI; and (3) potential and challenges of applying RDI in large-scale agriculture. The overall goal is to understand the science behind RDI, provide science-based recommendations on the implementation of this practice in agriculture, and improve water use efficiency (WUE) in crop production.

\section{Definition and main approaches}

RDI is generally defined as an irrigation practice whereby a crop is irrigated with an amount of water below the full requirement for optimal plant growth; this is to reduce the amount of water used for irrigating crops, improve the response of plants to the certain degree of water deficit in a positive manner, and reduce irrigation amounts or increase the crop's WUE. In the scientific literature, there are substantial variations in terms of the definition of "water deficit" for agricultural crops. To facilitate the analysis and summarization of the published research findings, we define water deficit at the following five levels:

1. Severe water deficit- soil water is less than $50 \%$ of the field capacity;

2. Moderate water deficit-soil water is remained between 50 to $60 \%$ of the field capacity;

3. Mild water deficit - soil water is remained between 60 to $70 \%$ of the field capacity;

4. No deficit or full irrigation - soil water is generally greater than $70 \%$ of the field capacity during the key plant growth period; and 
5. Over-irrigation - the amount of water irrigated may be greater than what plants would require for optimal growth.

These definitions provide a "standardized" approach with which water deficit treatments and the responses reported in various published studies can be assessed using a similar scale. There are three main RDI approaches in the production of agricultural crops, as follows.

\subsection{Stage-based deficit irrigation}

Stage-based deficit irrigation is defined as RDI applied at different stages of plant development, with water applied to meet full plant evapotranspiration (ET) at the critical growth stages and less applied at the non-critical growth stages. The principle behind this approach is that the response of plants to RDIinduced water stress varies with growth stages and that less irrigation applied to plants at non-critical stages may not cause significant negative impact on plant productivity even though it may reduce normal plant growth. To apply this approach effectively, one must predetermine the critical growth stages for a specific crop species and cultivar and evaluate the relative sensitivity of crop plants to water deficit at various stages in their life cycle.

The sensitivity of plant growth stage to water deficit can be affected by many factors, including climatic conditions, crop species and cultivars, and agronomic management practices, among others. For example, under a Mediterranean climate, the most sensitive growth stage of wheat (Triticum aestivum) is at stem elongation and booting, followed by anthesis and grain filling (García Del Moral et al. 2003). In North China Plains, wheat plants respond to water deficit more sensitively post-tillering than in the early stage (Kang et al. 2002). With a plant species, genotypes differ in photosynthesis rate, stomatal conductance, and transpiration rate, thus, expressing different degrees of responses to water stress (Hongbo et al. 2005).

Sensitivity to water deficit also depends on crop species. Rice (Oryza sativa) plants watered at a level equal to full field capacity during the active tillering stage significantly reduced the numbers of tillers, panicles, and spikelets and ultimately decreased grain yield (Ashraf et al. 2012). Cotton (Gossypium hirsutum L.) receiving mild deficit irrigation at the flowering and budding stages improved WUE compared to fully irrigated controls (Du et al. 2006). A short duration of water deficit during tasselling stages in maize (Zea mays) reduced biomass production by $30 \%$ and grain yield by up to $40 \%$ (Çakir 2004). In the southern High Plains of the USA, water stress reduced soybean (Glycine $\max$ ) yield by 9 to $13 \%$ when imposed during early flowering to full bloom stage, by $46 \%$ when imposed during early pod development, and by $45 \%$ when imposed during later podding (Eck et al. 1987). Furthermore, the sensitivity to water deficit is also influenced by agronomic management practices. For example, in a wheat-maize relay planting study, straw covering on the soil surface at the vegetative growth stage significantly reduced stress-induced plant damage and enhanced WUE than any other treatments in arid irrigation areas (Yin et al. 2015).

\subsection{Partial root-zone irrigation}

Partial root-zone irrigation (also called partial root-zone drying in some literatures) is the second most popular approach of RDI. Essentially, half of the root system is irrigated with a full amount, while the remaining half is exposed to drying soil (Fig. 1). Typically, this approach includes two types as follows:

1. Alternate partial root-zone irrigation (Fig. 1a). The watering and drying of root zone are alternated in a pre-set frequency that allows the previously well-watered side of the root zone to dry down while fully irrigating the previously dried root zones. The drying-wetting frequency is typically decided according to water requirements of the crop species, growth stages, and soil water holding capacity at the time irrigation is applied. The irrigated and partially dried sides of the root zone are interchanged in subsequent irrigations.

2. Fixed partial root-zone irrigation (Fig. 1b). During the entire growth period, approximately half of the root system is irrigated in a normal amount each time when irrigation is applied, and the remaining half is always exposed to drying soil.

In both approaches, it is assumed that (i) the fraction of the root system under the drying soil may respond to drying by sending a root-sourced signal to the shoot where stomata may close to reduce water loss through transpiration (Liu et al. 2006b; Sobeih et al. 2004), and (ii) by reducing the amount of water applied to plants, a small narrowing of the stomatal opening may occur which helps reduce water loss with little or no impact on plant photosynthesis (De Souza et al. 2005; Liu et al. 2004).

The concept of partial root-zone irrigation was originally derived from some split-root studies conducted in 1980s (Caradus and Snaydon 1986; Kirkham 1983), and later, alternate drying of part of the root zone with subsequent wetting was used as an acclimatization process in stress-related studies (Kang and Zhang 2004). Of the two types, approach (a) is more common than approach (b). In both approaches, the roots in the drying zone obtain substantially less irrigation water than the roots in the wet zone, even though no direct irrigation is applied to the dry zone. Under field conditions, the width of the root zone may vary with plant species and planting configurations.

Positive effects of partial root-zone irrigation have been shown in many crop species. The possible mechanism responsible for the positive effects may include the following: (i) 

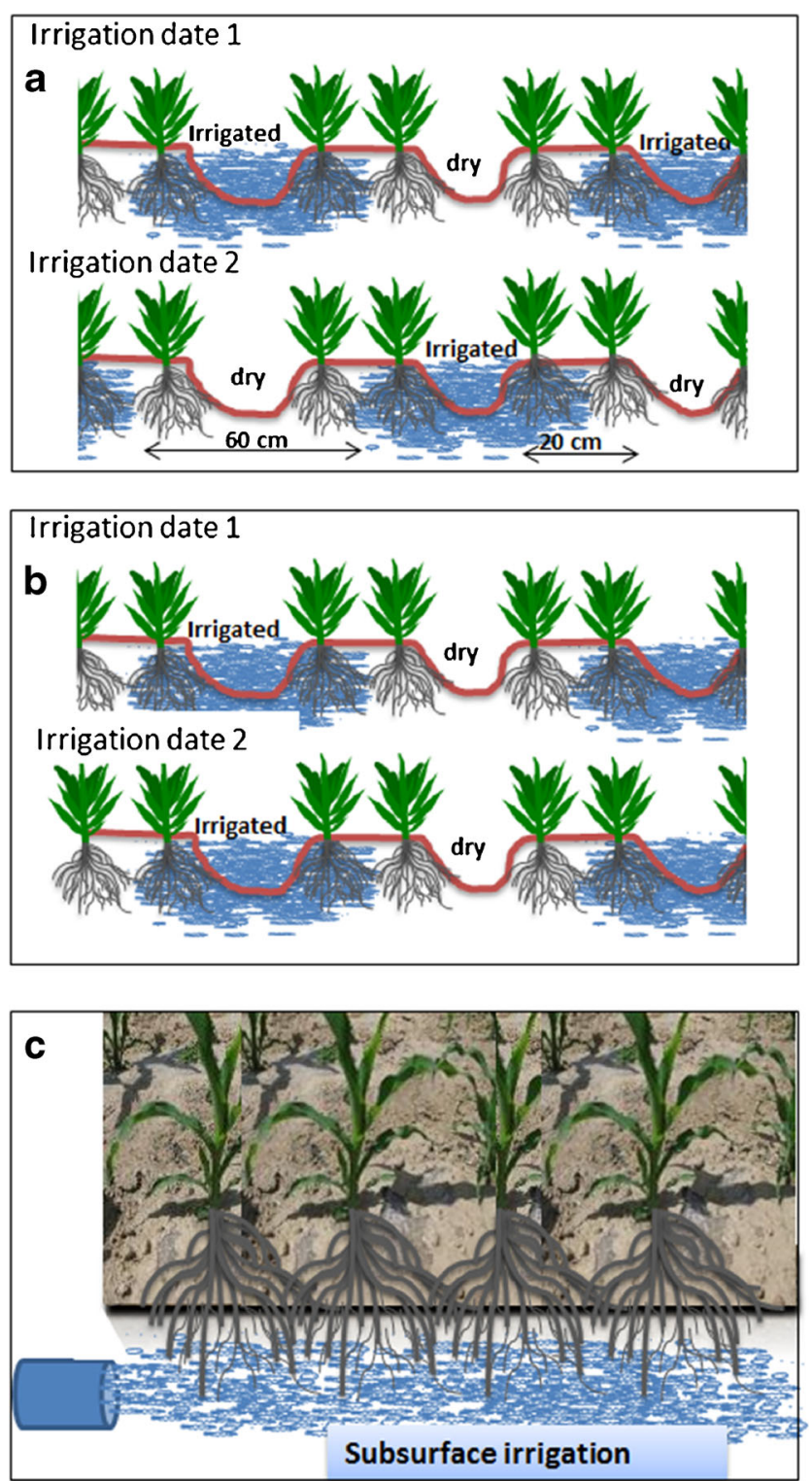

Fig. 1 Sketch of the main "regulated deficit irrigation" approaches, including a alternate partial root-zone irrigation where the two neighboring plant rows in every four rows are irrigated and they are shifted in consecutive irrigations, b fixed partial root-zone irrigation where the two neighboring plant rows in every four rows are irrigated every time and the remaining two rows of plants kept in drying soil, and $\mathbf{c}$ subsurface irrigation where irrigation is applied in the lower part of the root zone

inducing a compensatory effect of water uptake (Jarvis 2011) where the roots that have access to soil water (wet part of the zone) increase water uptake and to compensate for the roots that have little access to water (dry part of the zone), therefore upholding the full transpiration rate of the plant; (ii) reducing the surface areas for soil water evaporation; (iii) stimulating the growth of secondary roots and increasing root activity; and (iv) improving uptake of mineral nutrients and enhancing nutrient recovery in plants. More details on the physiological and biochemical aspects of the mechanisms are provided in Sect. 3).

\subsection{Subsurface irrigation or infiltration movement}

Subsurface irrigation is the third most popular RDI practice. Irrigation water is supplied to plants by capillary movement from the bottom (Fig. 1c). The root-zone air space is not immediately filled by water, in contrast with traditional irrigation where water is supplied directly overhead and water first fills the air space in the soil. Infiltration movement induces plant hardening or internal physiological regulations caused by mild water stress. A false signal of water deficit is transduced to the internals of the cell, where it induces apparent xerophytophysiological regulation with internal adjustment from the gene level to physiological levels $(\mathrm{Xu}$ et al. 2009a, 2011a, 2012). The plants under subsurface irrigation have been shown to maintain a high leaf turgor potential and a retention of a high symplastic water fraction that help plants to improve morphological strengthening, such as a thicker epidermis and more wax deposits on leaves and cuticle.

Subsurface irrigation is used mostly in nursery systems and, to a lesser extent, in the production of largescale field crops (Xu et al. 2009a). In nursing systems, potted soil or medium absorbs water through capillary absorption from the bottom of the pot, and then, water is transported into root zones. Under field conditions, irrigation water is usually supplied through a subsoil dripper system. Research shows that subsurface irrigation increases crop productivity and product quality. For example, tomato (Solanum lycopersicum L.) seedlings watered through subsurface irrigation dripper system increased both fruit yield and quality compared to the control where water was directly dripped to near the base of the plants (Xu et al. 2011b). Subsurface irrigation usually induces osmotic adjustment, increases leaf turgor potential, and consequently enhances photosynthetic activities (Xu et al. 2011b).

In some regions, supplementary irrigation is applied to crops in combination with soil surface covering. At the critical growth stages, dripper systems are used to provide supplemental water under the cover of plastic film (Fig. 2a). In other cases, some of the plant rows are irrigated and the other plant rows are left unirrigated but mulched with plastic films $(\mathrm{Hu}$ et al. 2015) (Fig. 2b). In areas with crop straw readily available, the straw is used to cover the soil surface of plant rows with alternate rows irrigated (Fig. 2c). All these techniques add benefits such as reduced soil evaporation and soil erosion, increased topsoil temperature with plastic cover in the early spring when soil temperatures are low, and improved soil nutrient availability to crops (Gan et al. 2013). 
Fig. 2 Sketch of the other "regulated deficit irrigation" approaches, including the following :a dripper systems are used to provide supplemental water under plastic film cover at critical growth stages; $\mathbf{b}$ some of the plant rows are irrigated, and the other plant rows left unirrigated are mulched with plastic films; and $\mathbf{c}$ alternate plant rows are irrigated, and the other plant rows left unirrigated are mulched with crop straw (photo taken from fields in northwest China in 2014)
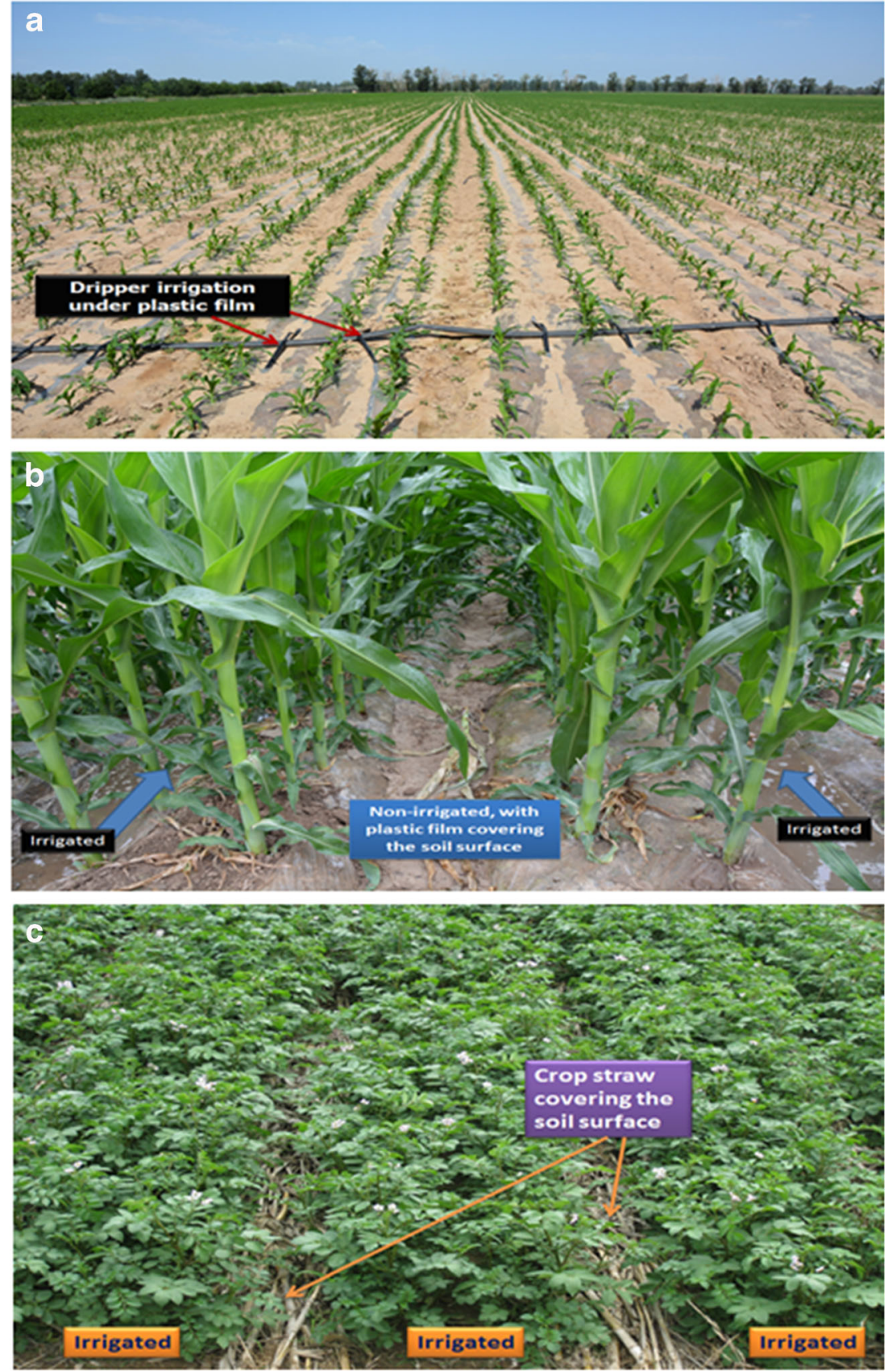

\section{Physiological basis}

RDI has been used as a means of saving water in agriculture since the early 1960s (Bouyoucos 1962; Grimes et al. 1969), but the physiological basis has not been well documented. During the past two decades, many researchers have focused on the determination of the mechanisms involved in the RDI approach which typically decreases water consumption and increases WUE with little or no yield penalty. Two basic theoretical assumptions have been made in this regard: (a) a small narrowing of stomatal opening under RDI-induced water deficit conditions may enhance leaf water retention and reduce water loss with little or no effect on photosynthesis, and (b) part of the root system in drying soil under partial root-zone irrigation sends an enzymebased signal to the shoots to stimulate stomatal closure and generate certain drought-tolerant mechanisms to act against water stress. There are a number of reports in the scientific literature that show how plants respond to RDI physiologically. The most common observations and expressions are as follows.

\subsection{Leaf water content}

Plant leaves are the key organ for transpiration and photosynthesis, and the complex anatomy of a leaf plays a crucial role 
in plant growth and development (Barbour and Farquhar 2004). A short period of mild water deficit under RDI may promote plants to reduce leaf water content or leaf water potential substantially (Liu et al. 2006a; Pérez-Pastor et al. 2014). Decreased leaf water potential acts as a hydraulic signal (along with chemical signals discussed in Sect. 4.1) triggering the reduced leaf area expansion and partial closure of stomata (Shahnazari et al. 2007).

Many factors influence the maintenance of leaf water potential under RDI; this depends on the intensity of water deficit applied (Liu et al. 2006a), crop growth stage (Li et al. 2010b), and duration of deficit (Xu et al. 2011a). In potato (Solanum tuberosum L), partial root-zone irrigation applied during the early growth period improved the fractional ratio of water in the cell symplasm to water in apoplasm and lowered the osmotic potential and relative water content at the point of incipient plasmolysis (Xu et al. 2011a). The early-season partial root-zone irrigation resulted in better use of soil water reserves through improved root to shoot ratio $(\mathrm{Li}$ et al. 2013), increased root biomass (Wang et al. 2012b), and enhanced root activity (Yang et al. 2012a). As a result, the early-season partial root-zone irrigation increased photosynthetic activity compared to that applied during the other growth stages.

Accurate measurement of leaf water potential is essential when assessing the response of plants to deficit irrigation. Many methodologies are available for this task, some being more preferable than others, depending on research preferences. Leaf water potential associated with RDI can be determined using the method, such as pressure chamber method (Sperry et al. 1996), hyperspectral indices (Yi et al. 2013), normalized spectral indices and ratio spectral indices (Cheng et al. 2011; Zhang et al. 2012), Mid-wave Infrared Normalized Difference Water Index (Ullah et al. 2013), near-infrared hyperspectral imaging (Higa et al. 2013), and microfabricated thermal sensor (Atherton et al. 2012), among others. We suggest that detailed experiments need to be conducted to compare which method would provide most accurate assessment of leaf water potential in response to RDI.

\subsection{Stomatal morphology}

An important physiological response to drought stress associated with RDI is stomatal characteristics, including stomatal opening and closing rhythms, the size of guard cells, and stomatal density. Guard cells regulate both the influx of $\mathrm{CO}_{2}$ as a raw material for photosynthesis and water loss from plants through transpiration to the atmosphere; thus, guard cells play a critical role in plant transpiration. In response to RDIinduced water stress, researchers have shown that guard cells trigger the process of stomatal closure (Schroeder et al. 2001), thus reducing water loss. Stomatal behavior of plants under RDI is regulated by chemical signals that provide the shoot with some indication of water availability. The central component of the signaling process involves the plant hormone abscisic acid that is produced in roots and shoot and moved to leaves where it triggers stomatal closure (Fig. 3). This process may be reversed once normal irrigation is applied (Schroeder et al. 2001). Also, stomatal density (Sun et al. 2013a), and changes in xylem sap $\mathrm{pH}$ are also involved in the response of plants to RDI-induced water stress. The redistribution of inorganic ions between different compartments in the leaf may provide sensitive control of stomata and water loss in response to water stress (Sobeih et al. 2004). More details on the involvement of the hormone in stomatal function are provided in Sect. 4.1.

In potato, partial root-zone irrigation significantly improved stomatal morphological characteristics compared with fully irrigated controls (Yan et al. 2012). Potato leaves under partial root-zone irrigation had smaller guard cells with lower stomatal density than the leaves under conventional irrigation, providing the benefits of reducing water loss from leaf surfaces (Cui et al. 2009a) and increasing net photosynthesis (Liu and Dickmann 1996).

\subsection{Photosynthesis and respiration}

Plants under mild deficit associated with RDI often express different levels of response in photosynthesis and respiration because RDI is implemented with different degrees of severity and at different growth stages (Sects. 2.1,2.2). A number of studies show that it is common that plants under partial rootzone irrigation can improve leaf transpiration (Du et al. 2006) and enhance photosynthesis rate (Romero et al. 2012) compared to the normal irrigation control. In the cotton study (Du et al. 2006), for example (Fig. 4), irrigation methods and the amounts of water applied had little or no effect on photosynthesis rate but had highly significant impacts on leaf respiration, seed yield, and WUE. It was consistent across the three water regimes (22.5- vs 30.0- vs 45.0-cm irrigation each time) that alternate partial root zone irrigation decreased transpiration, increased seed yield, and enhanced WUE significantly compared to the other irrigation methods. A low leaf transpiration rate with partial root-zone irrigation allows plants to use more photosynthates to form sinks (Shahnazari et al. 2007), increase carboxylation efficiency, or decrease carbon isotope discrimination and bundle-sheath cell leakiness to $\mathrm{CO}_{2}$ (Wang et al. 2012a). Increased leaf vapor pressure due to water deficit decreases the ratio of photosynthesis rate to transpiration rate, thus increasing transpiration efficiency (Shabani et al. 2013).

However, in other studies, plants grown under severe water stress reduce photosynthesis rate substantially (Romero et al. 2013). The magnitude of the photosynthetic response to RDI may vary with crop species. Under the same level of water deficit, mung bean (Vigna radiata) maintained a higher 
Fig. 3 Under drought stress with regulated deficit irrigation, plant hormone abscisic acid is produced in roots and shoot and acting as a signaling chemical to the leaves where it triggers stomatal closure

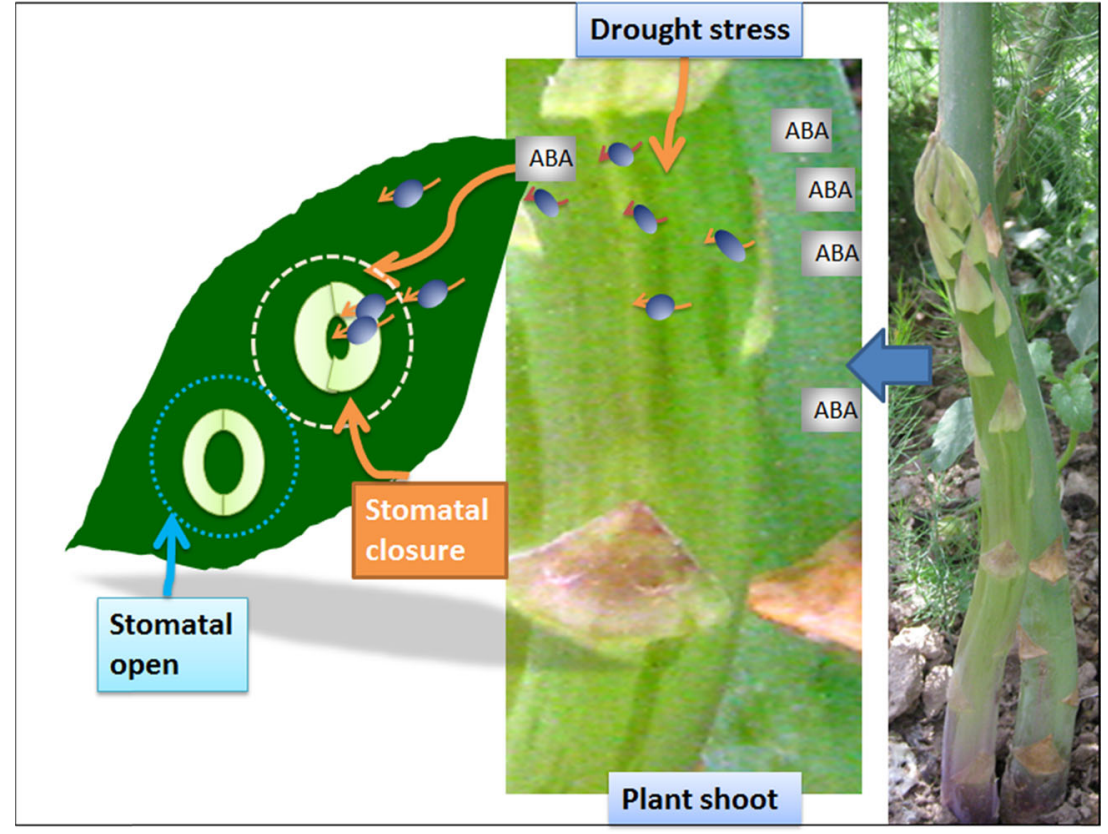

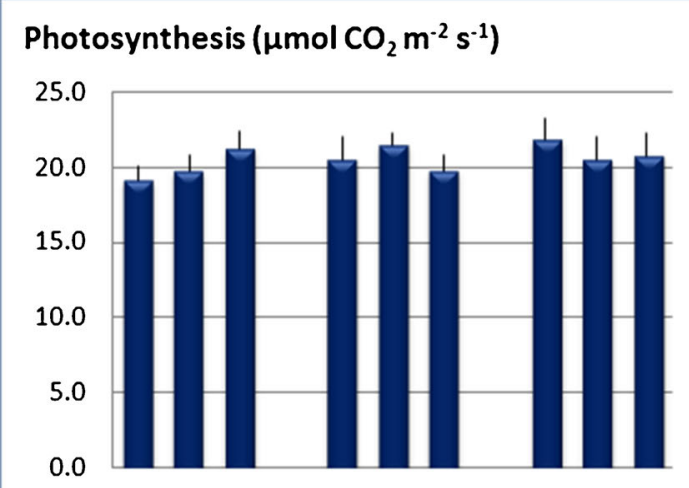

Seed yield ( $\left.\mathrm{kg} \mathrm{ha}^{-1}\right)$

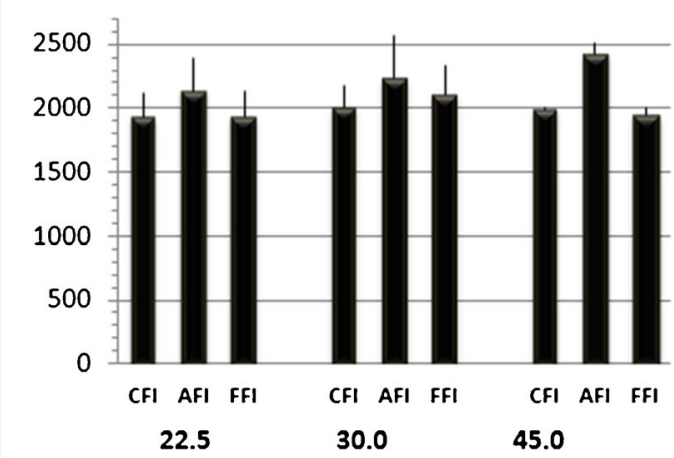

\section{Transpiration ( $\mathrm{mmol} \mathrm{H}_{2} \mathrm{O} \mathrm{m}^{-2} \mathrm{~s}^{-1}$ )}

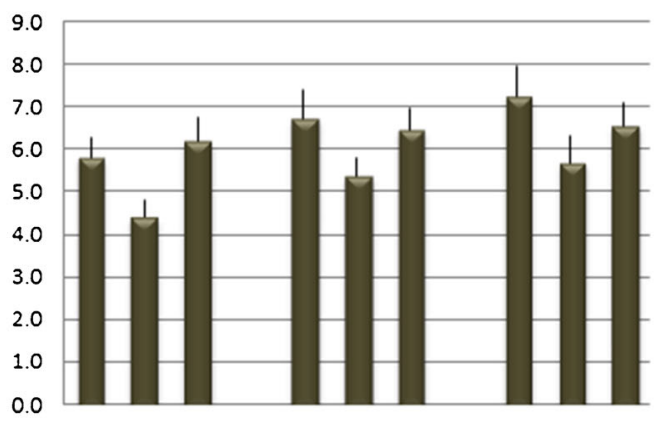

Water use efficiency $\left(\mathrm{kg} \mathrm{ha}^{-1} \mathrm{~mm}^{-1}\right)$

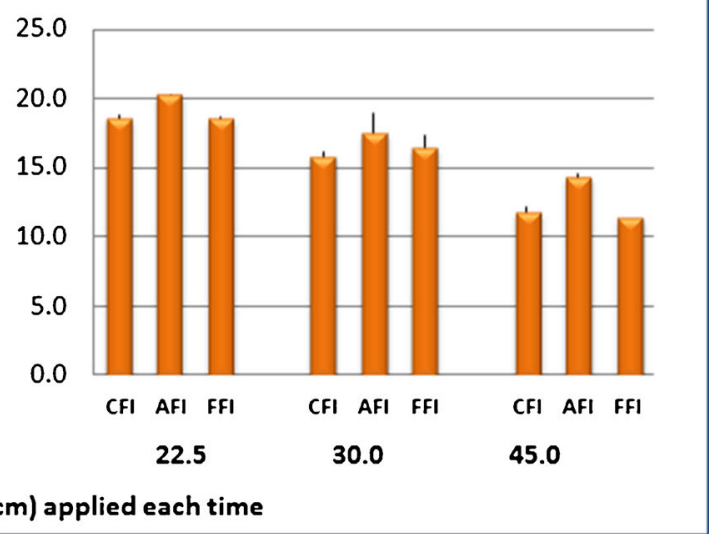

every two furrows irrigated), and a conventional irrigation method (CK). Vertical line bars are standard errors of the means (data source: Du et al. 2006)
Fig. 4 Photosynthesis rate, transpiration rate, seed yield, and water use efficiency of cotton irrigated with conventional furrow irrigation (CFI, all furrows were irrigated), alternate furrow irrigation (AFI, neighboring two furrows alternately irrigated), fixed furrow irrigation (FFI, fixed one of 
photosynthesis rate than common bean (Phaseolus vulgaris) with the same levels of transpiration (Bourgault et al. 2010).

\section{Biochemical basis}

\subsection{Plant hormones}

A number of studies have shown that in response to RDI, plants typically produce phytohormones (also known as plant growth regulators). These molecules, albeit in low concentration, regulate cellular processes in targeted cells, control the formation of flowers, stems, and leaves, and adjust the shedding of leaves and abscission of fruits. More importantly, these phytohormones act as signaling molecules, regulating a number of biochemical processes in plants and helping minimize the potential damage caused by RDI-induced water stress. Among the phytohormones is abscisic acid, a well-known plant growth regulator in plants. Since 1960s when abscisic acid was first discovered, this hormone has been studied extensively in many crop species. Under the RDI-induced water stress, biosynthesis occurs indirectly through the production of the organic pigment carotenoids in the chloroplasts and chromoplasts. Depending on the level of the stress, abscisic acid may follow different catabolic pathways (Balint and Reynolds 2013). At a low level of water stress, abscisic acid may be catabolized by conjugation to form abscisic acid glucose ester, whereas at a high level of water stress, the oxidation pathway is preferred, which is leading to the production of catabolites (phaseic acid or dihydrophaseic acid).

\subsection{Antioxidation enzymes}

Plants under RDI can alter their cellular metabolism and invoke various defense mechanisms. A major defense mechanism is the increased activity of antioxidation enzymes, such as superoxide dismutase, catalase, ascorbate peroxidase, guaiacol peroxidase, phenylpropanoid, lipoxygenase, and malondialdehyde contents in roots and leaves (Guidi et al. 2008; Hu et al. 2010; Sajedi et al. 2011; Sofo et al. 2004). With partial root-zone irrigation at mild water deficit level, some plant species maintain or increase the activity of those enzymes in leaves and roots (Hu et al. 2010). Usually, a higher degree of enzyme activity is required to improve the protection against pronounced oxidative stress.

Plant growth stages play an important role in the expression of enzymatic activities in leaves and roots under water deficit. For example, partial root-zone irrigation from jointing to tasselling did not cause damage to maize plants, as the accumulation of these substances prevents plant cell damage from water stress (Hu et al. 2010). However, water stress during the silking stage significantly reduced membrane permeability in maize leaves, as the expression of plasma membrane aquaporins (an intrinsic protein) in the leaf largely depends on the developmental stage of the leaf tissue (Hachez et al. 2008). Tomato plants under RDI increased peroxidase activity in cell walls rapidly during the initial phase of fruit setting, with enzymatic activity reaching the peak at the end of fruit ripening (Savić et al. 2008).

The activities of antioxidant enzymes under water stress vary among plant species or cultivars (Chaitanya et al. 2009). The sensitivity of the enzymatic response depends on intrinsic genetic traits in plants. In maize, drought-tolerant cultivars often express a higher concentration of superoxide anion radicals, malondialdehyde, and proline, along with higher activities of antioxidant enzymes compared to drought-sensitive cultivars (Sun et al. 2013a). The increased biochemical activity in stressed tissues can offset some of the reduced chlorophyll concentration and chlorophyll fluorescence under water stress. However, in some of the woody plant species, the opposite can be true. For example, olive tree (Olea europaea) is found to decrease enzymatic activities in leaves and roots under RDI-induced water stress (Sofo et al. 2004).

\subsection{Non-enzymatic substances}

Another important defense mechanism with RDI is the production of non-enzymatic substances, which consist of low-molecular-weight substances such as soluble sugars, proline (Mansouri-Far et al. 2010), and malondialdehyde in leaves (Sofo et al. 2004) and in roots (Hu et al. 2010). These substances regulate osmotic potential in plants by the law of mass action to reduce osmotic stress and enhance plant water holding capacity. Also, water stress can promote plants to produce other non-enzymatic substances such as carotenoids, nonprotein thiol (Mishra et al. 2013), polyphenols, and anthocyanins (Tahkokorpi et al. 2007). These substances may serve to decrease leaf osmotic potential, allowing leaves to tolerate suboptimal water levels. Leaf turgor maintenance caused by osmotic adjustment through solute accumulation is found in plants under subsurface irrigation (Xu et al. 2009a, 2011a, b).

\section{Plant water status under regulated deficit irrigation}

\subsection{Determination of water use efficiency}

Water use efficiency (WUE) serves as a key variable in the assessment of plant responses to RDI-induced water stress, because the outcome of using RDI in crop production is to assess the amount of irrigation that can be saved or the crop yield produced per unit of water supplied. Physiologically, 
WUE describes the intrinsic trade-off between carbon fixation and water loss, because water evaporates from the interstitial tissues of leaves whenever stomata open for $\mathrm{CO}_{2}$ acquisition for photosynthesis (Bramley et al. 2013). In plant research, WUE is defined as crop yield per unit of water used and calculated using the following formula:

$\mathrm{WUE}_{y}={ }^{Y} / \mathrm{ET}$

where $Y$ can be (a) economic yield in kilogram per hectare (e.g., grain yield in cereals, seed yield in legume and oilseed crops, tuber yield in potatoes and root crops, and leaf yield in vegetables), (b) biomass yield in kilogram per hectare, or (c) energy yield ( $\mathrm{MJ} \mathrm{ha}^{-1}$ ) (Chai et al. 2014b), depending on the nature of the study. In all cases, the denominator ET $(\mathrm{mm})$ is the total actual evapotranspiration. Thus, the unit of WUE is typically expressed in kilogram per hectare per millimeter. In some cases, the term precipitation use efficiency (PUE) (Gan et al. 2013) or irrigation water use efficiency (Sun et al. 2010) is used to describe the efficiency of precipitation during the growing season or the amount of irrigation applied to the crop, respectively.

In the cases of RDI in crop production, the total and/or irrigation WUE is most popularly used, which is defined as follows:

$\mathrm{WUE}_{i}=\frac{(Y i-Y d)}{I r}$

where $Y i$ is the crop yield with irrigation and $Y d$ is the crop yield without irrigation or an equivalent rainfed field and $I r$ is the amount of irrigation water applied. The unit of $\mathrm{WUE}_{i}$ is kilogram per hectare per millimeter.

In some cases, $\mathrm{WUE}_{j}$ is also expressed as the ratio of photosynthesis rate to transpiration rate or the ratio of photosynthesis rate to stomatal conductance of $\mathrm{CO}_{2}$ (Bramley et al. 2013; Cui et al. 2009a), as follows:

$\mathrm{WUE}_{j}=\frac{\text { Photosynthesis rate }}{\text { Transpiration rate }}$ or $\frac{\text { Photosynthesis rate }}{\text { Stomatal conductance of } \mathrm{CO}_{2}}$

Additionally, crop water productivity (CWP), an alternative term, has been used for the expression of WUE by some irrigation managers and is defined as follows:

$\mathrm{CWP}=\frac{Y}{10 \mathrm{ET}}$

where CWP has a unit of kilogram per cubic meter, $Y$ is the crop yield $\left(\mathrm{kg} \mathrm{ha}^{-1}\right)$ and ET is total ET over the entire growing season (mm). Because 1 ha is $10,000 \mathrm{~m}^{2}, 1 \mathrm{~mm}(0.001 \mathrm{~m})$ of ET from 1 ha of cropped land equates to $10 \mathrm{~m}^{3}$. Thus, the ET denominator is multiplied by 10 to obtain the CWP in kilogram per cubic meter.

\subsection{Improvement of water use efficiency under regulated deficit irrigation}

Most of the studies that we have reviewed show that the foremost benefit of using RDI is to reduce the amount of irrigation and increase WUE, but crop yield can be increased, maintained, or decreased (Table 1); this has been demonstrated in many crop species such as green gram (Vigna radiata $\mathrm{L}$.) (Webber et al. 2006), maize (Li et al. 2013), potato (Xie et al. 2012), and tomato (Wang et al. 2010a), as well as some woody plant species, such as pear-jujube tree (Zizyphus jujube Mill.) (Cui et al. 2009a), almond (Prunus dulcis Mill.) (Egea et al. 2011), apple (Van Hooijdonk et al. 2004), and peach (Prunus persica L) (Geiiy et al. 2004).

The following are some typical WUE examples. In a controlled-environment study with maize, partial root-zone irrigation applied at the jointing stage reduced water consumption by $12 \%$ and enhanced WUE by $12 \%$ (Li et al. 2010a); partial root-zone irrigation applied from jointing to tasselling reduced water consumption by $32 \%$ and enhanced WUE by $41 \%$. In sunflower (Helianthus annuus) grown in a semiarid area of Italy, small $(150 \mathrm{~mm})$ to moderate $(270 \mathrm{~mm})$ amounts of water ensured an average seed yield but with water saving by 74 and $53 \%$, respectively, compared to the fully irrigated control treatment (Garofalo and Rinaldi 2015). In a study with potato, partial root-zone irrigation reduced water use by nearly $50 \%$ without reducing potato tuber yield, thus increasing potato WUE by more than $50 \%$ (Xie et al. 2012). In tomato, the application of full irrigation until the beginning of the fruit ripening stage and the cessation of irrigation thereafter saved irrigation water by $33 \%$ and increased WUE by $42 \%$ with a $5 \%$ yield loss (Kuşçu et al. 2014). Such a water saving phenomenon is also reported in woody plant species. In apple, use of partial root-zone irrigation helped save irrigation water by $780,000 \mathrm{~L}$ per hectare (or $49.8 \%$ ) compared to the fully irrigated control treatment without affecting apple yield (Van Hooijdonk et al. 2004). In a 6-year study with 'Clementina de Nules' citrus trees, use of RDI ensured a water saving of $15 \%$ annually without impacting fruit yield (Ballester et al. 2014). In a 5-year study with Japanese plum (Prunus thibetica), RDI applied post-harvest at 60 and $30 \%$ of the control (which had 639-mm irrigation annually) helped save irrigation by 39 and $70 \%$, respectively, compared to the control, without causing reduction in fruit yield or quality (Samperio et al. 2015).

\subsection{Mechanisms involved in improved water use efficiency}

A number of mechanisms are responsible for the reduced water use or increased WUE for the plants under RDI-induced water stress. Those plants under mild water deficit may be able to perform one or more of the following: 
Table 1 Examples of the effects of partial root-zone deficit irrigation, compared to full irrigation on water use efficiency and crop yields in some selected arid and semiarid areas

\begin{tabular}{|c|c|c|c|c|c|}
\hline Study site & & Study year & Crop & $\begin{array}{l}\text { Partial root-zone deficit irrigation over } \\
\text { full irrigation }\end{array}$ & Reference \\
\hline \multicolumn{6}{|l|}{ Water use efficiency } \\
\hline Minqin, Gansu & $38^{\circ} 05^{\prime} \mathrm{N}, 103^{\circ} 03^{\prime} \mathrm{E}$ & 2004-2005 & Cotton & $\begin{array}{l}\text { Saved } 31-33 \% \text { of irrigation water, } \\
\text { increased WUE by } 5-21 \% \text { over } \\
\text { full irrigation }\end{array}$ & Du et al. (2008a) \\
\hline Shenyang, Liaoning & $41^{\circ} 31^{\prime} \mathrm{N}, 123^{\circ} 24^{\prime} \mathrm{E}$ & 2007 & Tomato & $\begin{array}{l}\text { Increased WUE on fresh yield by } \\
52 \% \text {, mainly due to reduced } \\
\text { transpiration rate }\end{array}$ & Yang et al. (2012a) \\
\hline Lima, Peru & $12^{\circ} 05^{\prime} \mathrm{W}, 76^{\circ} 55^{\prime} \mathrm{S}$ & 2010 & Potato & $\begin{array}{l}\text { Saved water consumption by } \\
32-54 \% \text { over full irrigation } \\
\text { with early deficit application } \\
\text { without yield penalty }\end{array}$ & Yactayo et al. (2013) \\
\hline Yangling, China & $34^{\circ} 18^{\prime} \mathrm{N}, 108^{\circ} 24^{\prime} \mathrm{E}$ & 2008 & Maize & $\begin{array}{l}\text { Saved water by } 11-32 \% \text {; } \\
\text { increased canopy WUE by } \\
10-42 \%\end{array}$ & Li et al. (2010a) \\
\hline Shiraz, Iran & $\left(29^{\circ} 36^{\prime} \mathrm{N}, 52^{\circ} 32^{\prime} \mathrm{E}\right.$ & 2012 & Potato & $\begin{array}{l}\text { Saved water by } 28 \% \text {, but decreased } \\
\text { water productivity (kg per } \mathrm{m}^{-3} \\
\text { of water) by } 35 \% \text { due to } \\
\text { decreased yield }\end{array}$ & Ahmadi et al. (2014) \\
\hline Tarsus, Turkey & $37^{\circ} 01^{\prime} \mathrm{N}, 35^{\circ} 01^{\prime} \mathrm{E}$ & $2006-2007$ & Sunflower & $\begin{array}{l}\text { Saved water by } 36 \% \text {, increased } \\
\text { irrigation water use efficiency } \\
\text { by } 33 \% \text { but decreased seed yield }\end{array}$ & Sezen et al. (2011) \\
\hline Portici, Italy & $40^{\circ} 31^{\prime} \mathrm{N}, 14^{\circ} 58^{\prime} \mathrm{E}$ & 2 years & Tomato & $\begin{array}{l}\text { WUE (in terms of marketable } \\
\text { yield per unit of actual } \\
\text { evapotranspiration) did not differ }\end{array}$ & $\begin{array}{l}\text { Casa and Rouphael } \\
\text { (2014) }\end{array}$ \\
\hline \multicolumn{6}{|l|}{ Crop yield } \\
\hline Minqin, Gansu & $38^{\circ} 05^{\prime} \mathrm{N}, 103^{\circ} 03^{\prime} \mathrm{E}$ & 2004-2005 & Cotton & $\begin{array}{l}\text { Increased seed-cotton yield } \\
\text { by } 5-21 \% \text { over full irrigation, } \\
\text { due to improved harvest index }\end{array}$ & Du et al. (2008a) \\
\hline South Jutland, Denmark & $54^{\circ} 54^{\prime} \mathrm{N}, 9^{\circ} 07^{\prime} \mathrm{W}$ & 2004-2005 & Potato & $\begin{array}{l}\text { Improved the marketable class of } \\
\text { potato tubers by as high as } 20 \% \text {; } \\
\text { no yield penalty, with } \\
30 \% \text { water reduction }\end{array}$ & $\begin{array}{l}\text { Shahnazari et al. } \\
\text { (2007) }\end{array}$ \\
\hline Gangu, China & $36^{\circ} 2^{\prime} \mathrm{N}, 103^{\circ} 40^{\prime} \mathrm{E}$ & 2011 & Wheat & $\begin{array}{l}\text { Decreased grain yield by } 43 \% \text { due to } \\
\text { water stress imposed during } \\
\text { reproductive growth stage }\end{array}$ & Ma et al. (2014) \\
\hline Shiraz, Iran & $\left(29^{\circ} 36^{\prime} \mathrm{N}, 52^{\circ} 32^{\prime} \mathrm{E}\right.$ & 2012 & Potato & $\begin{array}{l}\text { Decreased tuber yield by an average } \\
\text { of } 54 \%\end{array}$ & Ahmadi et al. (2014) \\
\hline Jumilla, SE Spain & $38^{\circ} 23^{\prime} \mathrm{N}, 1^{\circ} 25^{\prime} \mathrm{W}$ & 1999-2001 & Grape & $\begin{array}{l}\text { Increased berry yield by } 0-43 \% \text {, } \\
\text { due to promotion of shoot length, } \\
\text { pruning weight, berry number } \\
\text { per cluster, and cluster weight }\end{array}$ & De la Hera et al. (2007) \\
\hline Tarsus, Turkey & $37^{\circ} 01^{\prime} \mathrm{N}, 35^{\circ} 01^{\prime} \mathrm{E}$ & 2006-2007 & Sunflower & $\begin{array}{l}\text { Decreased seed yield by } 15 \% \text { due to } \\
\text { lowered seeds per heat and weight } \\
\text { per seed }\end{array}$ & Sezen et al. (2011) \\
\hline Portici, Italy & $40^{\circ} 31^{\prime} \mathrm{N}, 14^{\circ} 58^{\prime} \mathrm{E}$ & 2 years & Tomato & $\begin{array}{l}\text { Decreased fruit yield by } 52 \% \text { due } \\
\text { to lowered fresh weight }\end{array}$ & $\begin{array}{l}\text { Casa and Rouphael } \\
\text { (2014) }\end{array}$ \\
\hline
\end{tabular}

1. Enhance guard cell signal transduction network that controls water loss from leaves through transpiration to the atmosphere (Schroeder et al. 2001);

2. Promote higher osmotic adjustment particularly when mild water stress is applied in early growth stages (Yactayo et al. 2013);

3. Allow the development of drought hardiness by partial drought stimulations (Xu et al. 2011a), where multiple cellular tolerance pathways operate in a coordinated manner in drought-tolerant plants (Parvathi et al. 2013);

4. Optimize stomatal control over gas exchange (Wang et al. 2010a), improving the ratio of photosynthesis to transpiration or to stomatal conductance of $\mathrm{CO}_{2}$ (Cui et al. 2009a);

5. Reduce "luxury" transpiration loss without or with a minimal impact on photosynthesis (Yang et al. 2012a); and finally 
6. Improve moisture distribution across the soil profile and reduce potential evaporation due to decreased evaporative surface areas exposed by the partial root-zone irrigation approach (Xie et al. 2012).

\section{Agronomic practices for improving crop productivity under regulated deficit irrigation}

RDI has been used for many field crops such as wheat (Hongbo et al. 2005), maize (Liang et al. 2013; Wang et al. 2012b), cotton (Du et al. 2008b; Li and Lascano 2011; Ünlü et al. 2011), rapeseed (Brassica napus) (Hamzei and Soltani 2012), soybean (Mishra et al. 2013), common bean (Simsek et al. 2011), mung bean (Bourgault et al. 2010), sunflower (Garofalo and Rinaldi 2015), potato (Ahmadi et al. 2014), and tomato (Wang et al. 2013). And, this technology has been used in some woody plant species, such as grapevine (Romero et al. 2012), apple (Yang et al. 2012b), olive trees (Ghrab et al. 2013), nectarine (Prunus persica L.) (De la Rosa et al. 2015), and wine grape (Vitis vinifera L.) (De la Hera et al. 2007). Here, we summarize the key agronomic traits of plants in response to RDI-induced water stress and discuss some of the key agronomic strategies and practices to improve the growth and development and plant yield and product quality under RDI-induced water stress.

\subsection{Promoting plant growth and development}

The majority of the studies that we have reviewed show that RDI places plants in a mild water stress condition for a short period of time, and once full irrigation is applied, normal plant growth and development resumes, and plants are rapidly recovered to a level similar to the fully irrigated controls. A short period of mild water deficit promotes plant development with a positive effect on plant growth. For example, in maize, the growth and development of water-stressed plants rapidly recovered to the control level only 3 days after being re-watered (Kang et al. 2000).

Timing and the extent to which RDI is applied plays a critical role in plant recovery from deficit-induced stress. In maize, deficit irrigation applied during the vegetative stage increased grain yield by 10 to $20 \%$ compared to the stress retained during the whole growth cycle (Domínguez et al. 2012). Maize plants treated with mild water deficit (defined in Sect. 2 above) at the seedling and stem elongation stages showed a positive "transferring effect" from early to later growth stages (Kang et al. 2000). Compared to the fully irrigated control, the maize plants that recovered from the seedling-stage water stress were better adapted to soil water deficit occurring later in the life cycle. However, long-term severe water deficits can have a significant, negative impact on plant growth (Siddique and Bramley 2014). These studies clearly show that a mild water stress can be applied at the early growth stage through RDI; this will improve the adaptability of plants to the stress through a stress-induced acclimatization process.

\subsection{Stimulating root activity}

There are a limited number of reports in the scientific literature that assessed the effect of RDI on plant roots. Some recent publications show that RDI generally increases root to shoot ratio (Vandoorne et al. 2012; Wang et al. 2012b). In a climatecontrolled environmental study, maize plants under alternate partial root-zone deficit irrigation produced $49 \%$ more root biomass and increased root to shoot ratio by $54 \%$, compared to the fully irrigated control (Wang et al. 2012b). This is a typical example where mild water stress associated with RDI has little or no effect on shoot biomass, but it promotes root growth significantly (Fig. 5). Consequently, the increased root to shoot ratio provides benefits for water and nutrient uptake once full irrigation resumes. Similarly, in cotton, alternate partial root-zone irrigation stimulated the growth of secondary roots (Du et al. 2008a). The increased secondary roots, along with increased root to shoot ratio, are beneficial for improving water absorption (Li et al. 2013) and enhancing soil nutrient uptake (Hu et al. 2009; Wang et al. 2012b). This phenomenon, commonly observed under alternate partial root zone strategy, has been validated using simulation models ( $\mathrm{Li}$ et al. 2013).

In plant research, "root activity" has been used to evaluate the metabolic capacity of a root system. Root activity is usually measured using triphenyl tetrazolium chloride (Upadhyaya and Cladwell 1993). Roots are washed with deionized water and excised at a certain length from the root tips, and root tips are allowed to react with triphenyl tetrazolium chloride in phosphate buffer solution. After a certain time, sulfuric acid is added to stop the reaction. The extraction of root tips is then measured with dehydrogenases. Dehydrogenase activity is regarded as an indicator of root activity which has a direct effect on the ability of the roots to absorb water and minerals from soils. Alternate partial root-zone irrigation has been shown to increase root activity in tomato plants by 48 to $59 \%$ compared to the conventional irrigation control (Yang et al. 2012a). Watering alternation between drying and wetting root zones with partial root-zone irrigation allows roots to experience mild water stress first, and then, re-watering provides a compensatory effect in enhancing root activity.

These studies indicate that partial root-zone deficit irrigation has a compensatory effect to stimulate root growth and increase the root shoot ratio, helping stress-treated plants to recover rapidly once normal irrigation is resumed later in their life cycle. Plant growth-promoting rhizobacteria have been found to colonize plant roots and increase root growth under 
Fig. 5 Maize plants under alternate partial root-zone deficit irrigation (PRD) produced a greater (49 \% more) amount of root biomass with increased (by $54 \%$ ) root to shoot ratio, compared to maize plants under full irrigation (FI, the control) or the conventional deficit irrigation (DI). Different letters in a subpanel indicate significant differences $(P<0.05)$ between the treatments (data source: Wang et al. 2012b)

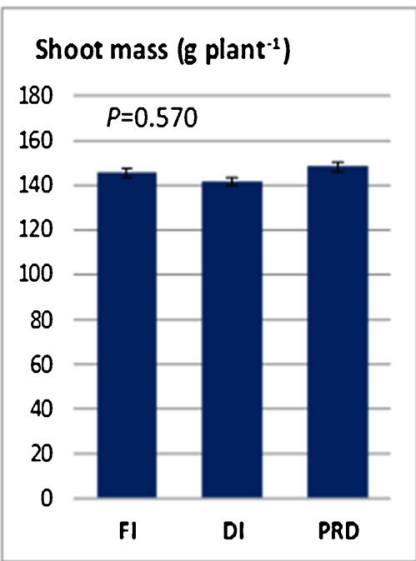

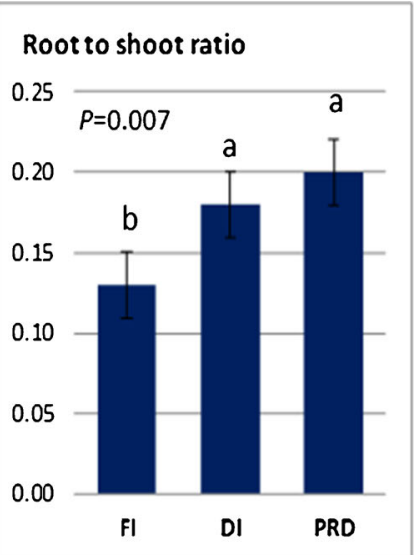

water stress (Prudent et al. 2015). Also, the use of thuricin-17 under water stress can modify rooting systems and increase root and nodule biomass in soybean.

However, the effect of RDI on root activity may not occur in some plant species. For example, partial root-zone irrigation has no effect on root growth in oilseed rape (Wang et al. 2009). The tap and lateral rooting nature of oilseed allows the plants to root vertically and horizontally in response to water availability in the soil. The strong plasticity allows oilseed plants to maintain the root system that facilitates the use of rainfall and irrigation when water is available in the top soil layers and root deeper in the soil layers to absorb available water particularly under water deficit (Gan et al. 2009). In this case, water deficit treatments have little to no signaling effect.

\subsection{Maintaining or increasing plant yield}

Deficit irrigation applied at the early growth stage or partial root-zone deficit irrigation has been shown to maintain or even increase yields in many field crops. In a ridge-furrow planting of cotton in arid northwest China, irrigation to alternate furrows (i.e., half the furrows were irrigated with a full amount of water while the other half were exposed to drying) increased cotton yield by 13 to $24 \%$ (Du et al. 2006). Mild water deficit applied in the early stage is shown to enhance the level of drought resistance later in the life cycle and consequently maintain (Liu et al. 2006a) or even increase plant yields (Cui et al. 2009b; Xue et al. 2006). Mechanisms responsible for the increased plant productivity under RDI are not well understood. However, we find the following three key factors that may have contributed to the increased plant productivity:

1. Mild deficit at the seedling stage stimulates root development and increases root to shoot ratio, so that the plants are better equipped for soil water deficit at the later stages,

2. Plants with deficit irrigation at the vegetative stage increase the remobilization of pre-anthesis carbon reserved in the vegetative tissues to the grains (Xue et al. 2006), and

3. Water deficit reduces the growth redundancy of stem and leaves and promotes the translocation of photosynthetic assimilates to the final products (Du et al. 2008a).

However, water deficit applied during reproductive stages typically decreases crop yield. Usually, a yield reduction is unavoidable even though water stress during grain filling can promote the remobilization of the preand post-anthesis carbon reserves to the developing grains (Fig. 6). In this particular example (Ma et al. 2014), wheat plants under stress contributed $37 \%$ more dry matter reserved in the vegetative tissues to the grain compared to wheat plants that were grown under no stress condition, but this compensatory effect from the increased percent dry matter remobilization was not sufficient enough to offset lost yield due to water deficit applied in the reproductive stage. Similarly, in root chicory (Cichorium intybus var. sativum), a cash crop cultivated for inulin production in western Europe, plants exposed to water stress during the last half of their life cycle drastically decreased fresh and dry weight in shoot and roots, leading to a significant decrease in inulin yield even though the plants expressed high levels of drought tolerance (Vandoorne et al. 2012). Similar observations are reported in some woody plant species. RDI applied to apricot trees (Prunus armeniaca L.) at the amount of $50 \%$ of the seasonal ET significantly reduced trunk growth and pruning and decreased the number of fruits per tree and overall fruit yields (Pérez-Pastor et al. 2014). These studies suggest that farm managers could apply a mild to moderate degree of water deficit at the early growth stage, which can restrain growth redundancy, optimize the relationship between vegetative growth and reproductive growth, and maintain or increase plant yield, but RDI applied at the reproductive growth stage can decrease crop yields substantially. 


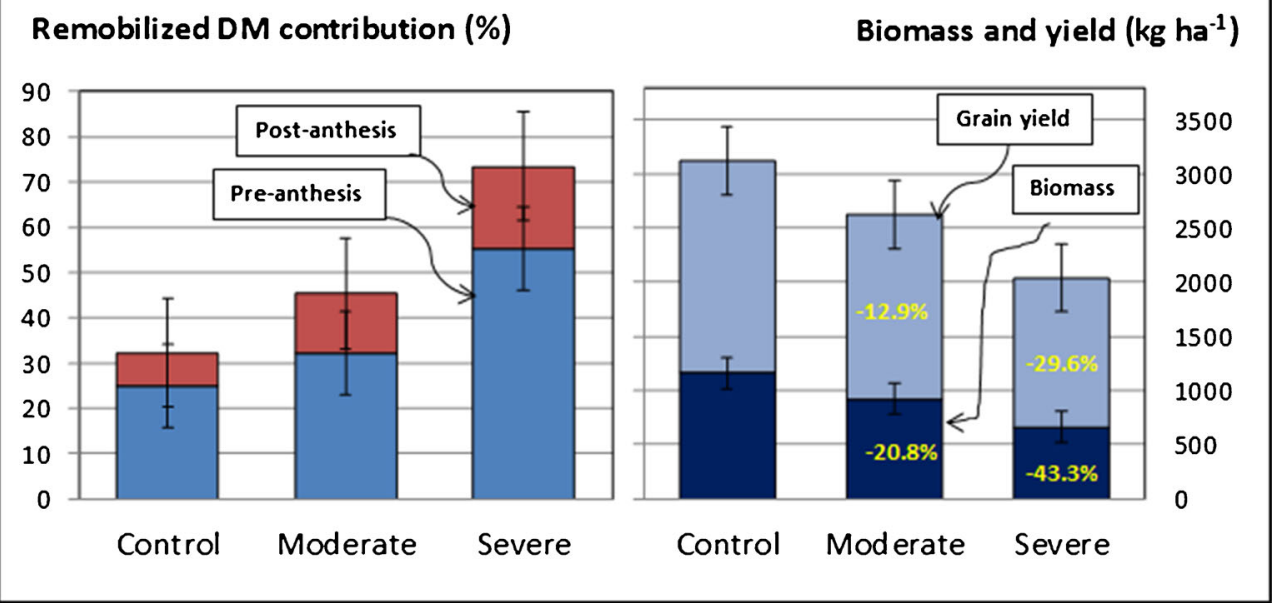

Fig. 6 Percent dry matter remobilized from the vegetative tissues to the grains during the pre-anthesis and post-anthesis periods (left) and aboveground biomass and grain yield (right) of spring wheat grown under non-stress control and moderate and severe water stress imposed

\subsection{Influencing product quality}

In the scientific literature, the effects of RDI on end-use quality of products are inconsistent, varying with crop species or the quality traits evaluated. Processing tomato crops grown under partial root-zone deficit irrigation increased solid content and improved taste and sensory quality (ZegbeDomínguez et al. 2003); potato grown under RDI during late tuber filling to maturing stages at a level near $60 \%$ of the control increased the proportion of marketable tuber class (by $20 \%$ ) compared to the fully irrigated control with no change in tuber yield (Shahnazari et al. 2007); tomato under RDI reduced the incidence and severity of blossom end rot (a troublesome disease affecting fruit quality), thus improving end-use quality (Sun et al. 2013b). However, oilseed rape under RDI decreased seed oil content substantially (Ghobadi et al. 2006); tomato under RDI decreased the size of the fruits (Kirda et al. 2007). In some of the woody plant species, inconsistent effects of RDI on product quality are obtained. In navel orange trees (Citrus sinensis L.), both fruit size and juice percentage were decreased whereas total soluble solid percentage and juice acid percentage increased (Hutton and Loveys 2011); in peach (Prunus persica L), RDI applied during the late part of fruit growth increased the ratio of soluble solid content to titratable acidity with a more reddish coloration on the fruit skin, representing a large improvement in fruit quality (Geiiy et al. 2004); in berry, water stress imposed through RDI substantially decreased color intensity, lowered sugar content, and reduced anthocyanin concentration (Romero et al. 2013). These examples show that RDI can help improve end-use quality attributes in some cases, but in other cases, deficit irrigation practice can have adverse effects on the end-use quality in some products. Farm managers will need to evaluate the effect of RDI on quality attributes for during grain filling. Vertical bars represent standard errors of the mean differences. The percentages on the bars represent the decreases of biomass and grain yield under the moderate and severe water stress compared to the control (data source: Ma et al. 2014)

each particular product to minimize the trade-off between saving certain amounts of irrigation and decreasing the end-use quality of the product.

\subsection{Improving nutrient use efficiency}

A number of studies have shown that crops with RDI can increase nutrient use efficiency through the promotion of nutrient recovery after a short period of water stress. For example, alternate partial root-zone irrigation to maize enhanced the ratio of $\mathrm{N}$ uptake in plants to the $\mathrm{N}$ supplied by $16 \%$ compared to fully irrigated control (Li et al. 2007); similarly, in a maize-wheat rotation study where full irrigation and partial root-zone deficit irrigation were compared in maize, partial root-zone irrigation increased $\mathrm{N}$ recovery by $17 \%$ compared to full irrigation (Kirda et al. 2005). Also, partial rootzone irrigation has been shown to improve agronomic $\mathrm{N}$ use efficiency, apparent $\mathrm{N}$ recovery efficiency, and $\mathrm{N}$ yield (Wang et al. 2013).

In this review, we find that the improved nutrient use with $\mathrm{RDI}$ is reflected in the following aspects:

1. Plants under mild deficit increase root surface area, root length density (Liu et al. 2011), and horizontal distance (Li et al. 2013) that facilitate nutrient uptake;

2. Drying and wetting cycles of root zones with partial rootzone irrigation improve the ability of plants to acquire nutrients from the soil, as drying and wetting cycles of soils stimulate the mineralization of soil organic N, thereby increasing mineral $\mathrm{N}$ available to plants;

3. Water deficit improves $\mathrm{N}$ distribution in the canopy with more $\mathrm{N}$ made available to the upper and middle portion of the leaf canopy (Wang et al. 2010a); 
4. Deficit irrigation decreases soil bulk density and percent water holding pores in the soil, facilitating $\mathrm{N}$ uptake by plants (El Baroudy et al. 2014);

5. Drying/wetting cycles with partial root zone irrigation enhance microbial activity with high microbial substrate availability which is partly responsible for the enhancement of net $\mathrm{N}$ mineralization in plants (Wang et al. 2010b); and

6. In some cases, drying and wetting cycles stimulate the colonization of arbuscular mycorrhizal fungi, stimulating the plants for nutrient uptake (Schreiner et al. 2007).

\subsection{Enhancing plant acclimatization through biochemical approaches}

Many agronomic strategies and practices can be used to stimulate plant growth and development and improve crop yields in association with the use of RDI for saving irrigation water. An innovative approach is to promote plants' photochemical efficiency through the use of bioinformatics (Kurz et al. 2010), genetic variations (Zhuang et al. 2007), and pharmacological means (Xu et al. 2009b) in improving water stress tolerance in plants. For example, the bacterium Pseudomonas syringae pv. syringae produces the compatible solutes betaine, ectoine, $\mathrm{N}$ acetylglutaminylglutamine amide, and trehalose (Kurz et al. 2010). These osmolytes can interact at the transcription level to yield a hierarchy of expression, contributing to water stress tolerance. Protein phosphorylation is shown to play an important role in regulating hydrogen peroxide accumulation in maize under water stress $(\mathrm{Xu}$ et al. 2009b). Some cross talk between protein phosphorylation and hydrogen peroxide accumulation may help enhance water stress defense systems. Also, transcriptional responses of identifiable genes can be regulated by water stress, and these stress-regulated transcripts are involved in cellular and biochemical activities, such as the function of carbohydrate metabolism and cell wall metabolism (Zhuang et al. 2007).

Furthermore, many practical crop management strategies can be employed to increase stress tolerance of plants under RDI (Romero et al. 2004). For example, the application of nitrogen to progressively drying soil can induce stomatal closure and minimize water loss (Liu and Dickmann 1996); the application of microelements can increase superoxide dismutase enzyme activity in the leaves of stressed plants and thus reduce the stress damage caused by water deficit (Sajedi et al. 2011); the application of bacterial endophytes to stressed plants can increase plant photochemical efficiency, reducing the leaf damage of relative membrane permeability caused by water deficit (Naveed et al. 2014).

\section{Opportunities and challenges}

\subsection{Opportunities}

Available water resources for agriculture have been rapidly decreasing in recent years due to increased competition for freshwater between agriculture and other sectors (Gan et al. 2013). RDI is considered a key water-saving practice for efficient use of the limited water resources (Chai et al. 2014a). In this review, we have identified that RDI can save irrigation water up to 20 to $30 \%$ and increase WUE up to $30 \%$ in the favorable situations. In some extreme cases, the RDI approach can save water up to $50 \%$ with a minimal impact on crop yield (Li et al. 2010a, b; Xie et al. 2012). However, the conventional irrigation that was used to compare with RDI in those extreme cases was usually schemed as "border irrigation" or "flood irrigation" in which plants may be overly irrigated which is not efficient in any standard. Among the RDI approaches, alternate partial root-zone irrigation has been found to be most effective and efficient in saving water and improving WUE while maintaining crop productivity (Hutton and Loveys 2011; Yactayo et al. 2013; Yang et al. 2012b).

Also, there are tremendous opportunities to combine the RDI practice with other advanced agronomic practices to enhance WUE in crop production. This may include (a) no-till management with cover crops (DeLaune et al. 2012), (b) subsurface tillage practices (Salar et al. 2013), (c) rotating tillage with no-till practices on farmland (Hou et al. 2012), (d) use of crop straw and plastic mulching (Yuan et al. 2014; Yin et al. 2015), (e) adoption of relay planting configuration (Yin et al. 2015), and (f) adoption of ridge-furrow planting configurations (Gan et al. 2013). Moreover, RDI can be combined with some modern irrigation techniques such as sprinkler irrigation (Bielorai 1982), surface drip irrigation (Du et al. 2008a; Faci et al. 2014), subsurface infiltration (DeLaune et al. 2012), and in combination with root-zone nutrient management through fertigation (Chen et al. 2011), to increase both water and nutrient use efficiencies. Additionally, the reallocation of water resources and modification of irrigation systems may have a role to play for the improvement of water use in agriculture (Homayounfar et al. 2014).

\subsection{Challenges}

The central novelty of RDI is that it allows plants to grow under mild water stress to induce root-sourced chemical signals from drying roots to reach the shoot where physiological and biochemical processes can be regulated. However, the physiological and biochemical responses are difficult to quantify, given that partial root-zone irrigation is usually applied to plants in accordance with both temporal and spatial droughts. In practice, adoption of water-saving technique requires scientific understanding of the mechanisms involved in the 
physiological and biochemical processes. Also, the outcome of the water stress-induced responses is influenced by many factors, such as the stages of crop growth when the deficit is applied, the intensity and severity of deficit imposed, the method with which deficit irrigation is applied, crop species and cultivars, and their respective non-critical growth stages when the stage-based deficit irrigation may be applied. These factors need to be investigated at a system level under specific growing conditions.

RDI and, particularly, alternate partial root-zone irrigation are still relatively new to manage farm managers. This technique is not easy to implement in crop species with dense plant population such as cereal and oilseed crops. Some standardized irrigation design may be required in order to ensure high irrigation efficiency. This may require (a) enacting rules or regulations to ensure that irrigation water is applied using a standard method, (b) educating end-users to realize the potential benefits and risks of yield penalty involved in the use of the deficit irrigation technique, (c) increasing sophisticated irrigation management tools coupled with cost-efficient irrigation equipment to facilitate implementation of this technique, and (d) analysis of cost-benefit ratio of using this technique in large-scale farming, especially for cash crops. Finally, it is extremely important that more experimental tests are needed to evaluate the response of specific crop species to RDI before the technique may be used extensively.

\section{Suggestions for future research}

In this review, we focus primarily on water stress-induced responses of plants, mainly morphological, physiological, and biochemical responses as well as their influence on crop productivity. We believe that more in-depth research is required to better understand the science beyond RDI. In addition, more applied techniques are required to facilitate application of this technique in large-scale agricultural systems. The real challenge is to establish RDI on the basis of delivering sustained or increased crop productivity, while saving irrigation water and enhancing WUE. Many topics or subject areas are needed to be studied in the near future; we suggest the following areas to be the top priorities.

\subsection{Signaling systems}

Abscisic acid, a naturally occurring compound in plants, has been considered the domain hormone in regulating stomatal opening and closure in plants under RDI-induced water stress. However, the current understanding of the pathway is narrow in some crop species. It is unclear how biosynthesis occurs in leaves and what catabolic pathways would be used under mild versus severe water stress. It is clear that with water stress, abscisic acid stimulates stomatal closure, inhibits shoot growth, and induces production of storage proteins relative to seed dormancy at maturity. However, it is unclear how the hormone functions to provide additional benefits to plants under stress, such as the potential role in defending pathogen attack or stimulating the development of root systems. Also, little has been documented in regard to other signaling systems, such as silicon which has been found to regulate the levels of endogenous plant hormones under stress conditions (Zhu and Gong 2014). However, silicon involvement in signaling and regulation of gene expression related to increasing stress tolerance remains to be explored.

\subsection{Physiological and biochemical responses}

There is a need to redefine major indicators of the effect of RDI on plant growth, photosynthesis and respiration, and biochemical responses in an effective manner. In the literature, it is unclear how to predict water consumption using the stomatal opening and closing mechanism, as stomatal control only constitutes part of the total transpirational resistance. Boundary resistance from the leaf surface to the outside of the canopy may be substantial such that any reduction in stomatal conductance may be partially compensated for by an increase in leaf temperature. Stomatal control over transpiration may differ between densely populated field crops, such as wheat, and fruit trees which are more sparsely planted. Little is known about how long stomata remain partially closed with prolonged soil drying and what role rewatering may play in stimulating root growth under drying soils. In this review, we find that the research on the plant-soil interactions, a way toward better crop water supply (Bodner et al. 2015), is still at infancy. One of the major areas in mitigating water stress may be focusing on the management of complex plant-soil interactions under site-specific conditions.

\subsection{Quantification of the magnitude of deficits}

There are inconsistent findings in the scientific literature with regard to the magnitude of water stress-induced responses to RDI. We believe that those inconsistencies are, to a large extent, caused by poorly designed experiments, inadequately defined treatment structures, and inconsistently managed testing conditions. A key component is that the irrigation water applied to plants should be based on the percentage of total crop ET, leaf water potential, or crop coefficients for a particular crop species of interest. Crops under deficit irrigation treatments must be really under water stress conditions with a quantitative measure. A fully irrigated control treatment may be, in fact, over-irrigated if the experimental treatments were not well designed or implemented. Investigation on smallgrain crops, such as wheat, maize, and rice, can be better controlled in terms of root water uptake and crop water consumption (for example, using lysimeters to determine kc 
factors) than deep rooting trees where it cannot be ruled out that reducing irrigation water is not compensated by water uptake through deep roots. The latter aspect needs to be quantified in future studies. Furthermore, it is important to develop and adapt a model-based approach to quantify the amounts of irrigation that can be applied to crops through deficit irrigation. Some of the models are quite promising such as AquaCrop model (Iqbal et al. 2014) and ORDI model (Domínguez et al. 2012), among others, and yet, their accuracy, efficiency, and effectiveness should be validated using multiple years of data.

\subsection{Potential impacts on soil quality attributes}

Deficit irrigation is an important strategy to manage water, but the relationship with soils is not well documented. For example, irrigation to the partial root zone may depend on soil type, as it is known that sandy soil may have a lot of water to flow downward whereas, for heavy clay soil, it will flow more horizontally. Also, the potential effects of deficit irrigation on soil physical and chemical properties have not been documented. We expect that drying and wetting cycles of soils with deficit irrigation may stimulate the mineralization of soil organic carbon and soil $\mathrm{N}$, leading to increased $\mathrm{N}$ bioavailability to plants, which may potentially increase $\mathrm{C}$ and $\mathrm{N}$ losses in the soil (Trost et al. 2013). Rarely, such information is found in the scientific literature. Similarly, there is a lack of information on soil physical properties such as aggregate stability, bulk density, particle size distribution, soil structural development, and inorganic carbon dynamics, as well as soil microorganism communities, structures, and their functionalities, in relation to water deficit. In some regions, soil salinity management goals may conflict with deficit irrigation goals. Determination of those soil quality-related parameters is needed to develop sustainable systems with water-saving approaches.

\section{Conclusion}

Water deficit is an inevitable consequence of life for terrestrial plants. A variety of mechanisms have evolved to control plant water status, regulate water loss, maintain turgor pressure, and reduce water transport out of plant systems. Many watersaving practices have been adapted to tackle the critical issue of water shortage worldwide. RDI, in the form of partial rootzone irrigation, stage-based deficit irrigation, infiltration water movement, and subsurface irrigation and supplemental irrigation, has been regarded as a key water-saving approach for the production of horticultural crops, field crops, and some woody plant species. In this review, we focus on the understanding of the physiological and biochemical mechanisms involved in the plant response to RDI-induced water stress. A mild water deficit applied at the early growth stages can provide large benefits to plant growth and development under certain conditions. In particular, a slowly increased water stress can induce internal physiological adjustments and regulations to protect plants from damage. Some of the key agronomic management strategies and practices can be employed to the adaptation of this technology in agriculture. No doubt, RDI practices can be adopted in real-world agricultural systems, but many theoretical and technical issues need to be solved. There is a need to define specific conditions under which RDI can be implemented effectively and efficiently and appropriate methodologies which can be successfully applied in large-scale fields. Some deficit irrigation methods, such as subsoil irrigation and horizontal infiltration movement, are still in the early stage of research and development. Whether or not these approaches can be profitably used on a large scale remains to be determined.

Open Access This article is distributed under the terms of the Creative Commons Attribution 4.0 International License (http:// creativecommons.org/licenses/by/4.0/), which permits unrestricted use, distribution, and reproduction in any medium, provided you give appropriate credit to the original author(s) and the source, provide a link to the Creative Commons license, and indicate if changes were made.

\section{References}

Ahmadi SH, Agharezaee M, Kamgar-Haghighi AA, Sepaskhah AR (2014) Effects of dynamic and static deficit and partial root zone drying irrigation strategies on yield, tuber sizes distribution, and water productivity of two field grown potato cultivars. Agric Water Manag 134:126-136. doi:10.1016/j.agwat.2013.11.015

Ashraf MA, Ashraf M, Shahbaz M (2012) Growth stage-based modulation in antioxidant defense system and proline accumulation in two hexaploid wheat (Triticum aestivum L.) cultivars differing in salinity tolerance. flora Morpho Distrib Funct Ecolo Plants 207:388-397. doi:10.1016/j.flora.2012.03.004

Atherton JJ, Rosamond MC, Zeze DA (2012) A leaf-mounted thermal sensor for the measurement of water content. Sensors Actuators, A: Phys 187:67-72. doi:10.1016/j.sna.2012.06.021

Balint G, Reynolds AG (2013) Impact of irrigation strategies on abscisic acid and its catabolites profiles in leaves and berries of baco noir grapes. J Plant Growth Regul 32:884-900. doi:10.1007/s00344013-9354-4

Ballester C, Castel J, El-Mageed TAA, Castel JR, Intrigliolo DS (2014) Long-term response of 'Clementina de Nules' citrus trees to summer regulated deficit irrigation. Agric Water Manag 138:78-84. doi:10. 1016/j.agwat.2014.03.003

Barbour MM, Farquhar GD (2004) Do pathways of water movement and leaf anatomical dimensions allow development of gradients in $\mathrm{H}_{2} \mathrm{O}$ between veins and the sites of evaporation within leaves? Plant Cell Environ 27:107-121. doi:10.1046/j.0016-8025.2003.01132.x

Bielorai $H$ (1982) The effect of partial wetting of the root zone on yield and water use efficiency in a drip- and sprinkler-irrigated mature grapefruit grove. Irrig Sci 3:89-100. doi:10.1007/BF00264852

Bodner G, Nakhforoosh A, Kaul HP (2015) Management of crop water under drought: a review. Agron Sustain Dev 35:401-442. doi:10. 1007/s13593-015-0283-4

Bourgault M, Madramootoo CA, Webber HA, Stulina G, Horst MG, Smith DL (2010) Effects of deficit irrigation and salinity stress on common bean (Phaseolus vulgaris L.) and mungbean (Vigna 
radiata (L.) Wilczek) grown in a controlled environment. J Agron Crop Sci 196:262-272. doi:10.1111/j.1439-037X.2009.00411.x

Bouyoucos GJ (1962) Hydrometer method improved for making particle size analyses of soils. Agron J 54:464-465. doi:10.1111/j.1439037X.2009.00411.X

Bramley H, Turner NC, Siddique KHM (2013) Water use efficiency. In: Kole C (ed) Genomics and breeding for climate-resilient crops 2., pp 225-268. doi:10.1007/978-3-642-37048-9 6

Çakir R (2004) Effect of water stress at different development stages on vegetative and reproductive growth of corn. Field Crops Res 89:116. doi:10.1016/j.fcr.2004.01.005

Caradus JR, Snaydon RW (1986) Plant factors influencing phosphorus uptake by white clover from solution culture-II. Root and shoot pruning and split-root studies. Plant Soil 93:165-174. doi:10.1007/ BF02374218

Casa R, Rouphael Y (2014) Effects of partial root-zone drying irrigation on yield, fruit quality, and water-use efficiency in processing tomato. J Hortic Sci Biotechnol 89:389-396. doi:10.1007/s10333-0090194-6

Chai Q, Gan Y, Turner NC, Zhang RZ, Yang C, Niu Y, Siddique KHM (2014a) Water-saving innovations in Chinese agriculture. Adv Agron 126:147-197. doi:10.1016/B978-0-12-800132-5.00002-X

Chai Q, Qin A, Gan Y, Yu A (2014b) Higher yield and lower carbon emission by intercropping maize with rape, pea, and wheat in arid irrigation areas. Agron Sustain Dev 34:535-543. doi:10.1007/ s13593-013-0161-x

Chaitanya KV, Rasineni GK, Reddy AR (2009) Biochemical responses to drought stress in mulberry (Morus alba L.): evaluation of proline, glycine betaine and abscisic acid accumulation in five cultivars. Acta Physiol Plant 31:437-443. doi:10.1007/s11738-008-0251-6

Chen XP, Cui ZL, Vitousek PM, Cassman KG, Matson PA, Bai JS, Meng QF, Hou P, Yue SC, Römheld V, Zhang FS (2011) Integrated soilcrop system management for food security. Proc Natl Acad Sci 108: 6399-6404. doi:10.1073/pnas.1101419108

Cheng T, Rivard B, Sánchez-Azofeifa A (2011) Spectroscopic determination of leaf water content using continuous wavelet analysis. Remote Sens Environ 115:659-670. doi:10.1016/j.rse.2010.11.001

Cui N, Du T, Kang S, Li F, Hu X, Wang M, Li Z (2009a) Relationship between stable carbon isotope discrimination and water use efficiency under regulated deficit irrigation of pear-jujube tree. Agric Water Manag 96:1615-1622. doi:10.1016/j.agwat.2009.06.009

Cui N, Du T, Li F, Tong L, Kang S, Wang M, Liu X, Li Z (2009b) Response of vegetative growth and fruit development to regulated deficit irrigation at different growth stages of pear-jujube tree. AgricWater Manag 96:1237-1246. doi:10.1016/j.agwat.2009.03. 015

De la Hera ML, Romero P, Gómez-Plaza E, Martinez A (2007) Is partial root-zone drying an effective irrigation technique to improve water use efficiency and fruit quality in field-grown wine grapes under semiarid conditions? Agric Water Manag 87:261-274. doi:10. 1016/j.agwat.2006.08.001

De la Rosa JM, Domingo R, Gómez-Montiel J, Pérez-Pastor A (2015) Implementing deficit irrigation scheduling through plant water stress indicators in early nectarine trees. Agric Water Manag 152:207-216. doi:10.1016/j.agwat.2015.01.018

De Souza CR, Maroco JP, Dos Santos TP, Rodrigues ML, Lopes C, Pereira JS, Chaves MM (2005) Control of stomatal aperture and carbon uptake by deficit irrigation in two grapevine cultivars. Agric Ecosyst Environ 106:261-274. doi:10.1016/j.agee.2004.10. 014

de Wit M, Stankiewicz J (2006) Changes in surface water supply across Africa with predicted climate change. Science 31(311):1917-1921. doi:10.1126/science. 1119929

DeLaune PB, Sij JW, Park SC, Krutz LJ (2012) Cotton production as affected by irrigation level and transitioning tillage systems. Agron J 104:991-995. doi:10.2134/agronj2011.0420
Domínguez A, de Juan JA, Tarjuelo JM, Martínez RS, Martínez-Romero A (2012) Determination of optimal regulated deficit irrigation strategies for maize in a semi-arid environment. Agric Water Manag 110: 67-77. doi:10.1016/j.agwat.2012.04.002

Du T, Kang S, Zhang J, Li F, Hu X (2006) Yield and physiological responses of cotton to partial root-zone irrigation in the oasis field of northwest China. Agric Water Manag 84:41-52. doi:10.1016/j. agwat.2006.01.010

Du T, Kang S, Zhang J, Li F (2008a) Water use and yield responses of cotton to alternate partial root-zone drip irrigation in the arid area of north-west China. Irrig Sci 26:147-159. doi:10.1007/s00271-0070081-0

Du T, Kang S, Zhang J, Li F, Yan B (2008b) Water use efficiency and fruit quality of table grape under alternate partial root-zone drip irrigation. Agric Water Manag 95:659-668. doi:10.1016/j.agwat.2008.01.017

Eck HV, Mathers AC, Musick JT (1987) Plant water stress at various growth stages and growth and yield of soybeans. Field Crops Res 17:1-16. doi:10.1016/0378-4290(87)90077-3

Egea G, Dodd IC, González-Real MM, Domingo R, Baille A (2011) Partial rootzone drying improves almond tree leaf-level water use efficiency and afternoon water status compared with regulated deficit irrigation. Funct Plant Biol 38:372-385. doi:10.1071/FP10247

El Baroudy AA, Ibrahim MM, Mahmoud MA (2014) Effects of deficit irrigation and transplanting methods of irrigated rice on soil physical properties and rice yield. Soil Use Manag 30:88-98. doi:10.1111/ sum. 12084

Faci JM, Blanco O, Medina ET, Martínez-Cob A (2014) Effect of post veraison regulated deficit irrigation in production and berry quality of Autumn Royal and Crimson table grape cultivars. Agrc Water Manag 134:73-83. doi:10.1016/j.agwat.2013.11.009

Farihi J, Gänsicke BT, Koester D (2013) Evidence for water in the rocky debris of a disrupted extrasolar minor planet. Science 342:218-220. doi:10.1126/science. 1239447

Forouzani M, Karami E (2011) Agricultural water poverty index and sustainability. Agron Sustain Dev 31:415-432. doi:10.1051/agro/ 2010026

Gan YT, Campbell CA, Janzen HH, Lemke RL, Basnyat P, McDonald CL (2009) Carbon input to soil from oilseed and pulse crops on the Canadian prairies. Agric Ecosyst Environ 132:290-297. doi:10. 1016/j.agee.2009.04.014

Gan Y, Siddique KHM, Turner NC, Li X-G, Niu J-Y, Yang C, Liu L, Chai Q (2013) Ridge-furrow mulching systems - an innovative technique for boosting crop productivity in semiarid rain-fed environments. Adv Agron 118:429-476. doi:10.1007/s11104-010-0312-7

García Del Moral LF, Rharrabti Y, Villegas D, Royo C (2003) Evaluation of grain yield and its components in durum wheat under Mediterranean conditions: an ontogenic approach. Agron J 95: 266-274. doi:10.2134/agronj2003.0266

Garofalo P, Rinaldi M (2015) Leaf gas exchange and radiation use efficiency of sunflower (Helianthus annuus L.) in response to different deficit irrigation strategies: from solar radiation to plant growth analysis. Eur J Agron 64:88-97. doi:10.1016/j.eja.2014.12.010

Geiiy M, Recasens I, Girona J, Mata M, Arbones A, Rufat J, Marsal J (2004) Effects of stage II and postharvest deficit irrigation on peach quality during maturation and after cold storage. J Sci Food Agric 84:561-568. doi:10.1002/jsfa.1686

Ghobadi M, Bakhshandeh M, Fathi G, Gharineh MH, Alami-Said K, Naderi A, Ghobadi ME (2006) Short and long periods of water stress during different growth stages of canola (Brassica napus L.): effect on yield, yield components, seed oil and protein contents. J Agron 5:336-341. doi:10.3923/ja.2006.336.341

Ghrab M, Gargouri K, Bentaher H, Chartzoulakis K, Ayadi M, Ben Mimoun M, Masmoudi MM, Ben Mechlia N, Psarras G (2013) Water relations and yield of olive tree (cv. Chemlali) in response to partial root-zone drying (PRD) irrigation technique and salinity 
under arid climate. Agrc Water Manag 123:1-11. doi:10.1016/j. agwat.2013.03.007

Girones R, Ferrús MA, Alonso JL, Rodriguez-Manzano J, Calgua B, de Abreu CA, Hundesa A, Carratala A, Bofill-Mas S (2010) Molecular detection of pathogens in water - the pros and cons of molecular techniques. Water Res 44:4325-4339. doi:10.1016/j.watres.2010. 06.030

Gleick PH, Palaniappan M (2010) Peak water limits to freshwater withdrawal and use. Proc Natl Acad Sci 107:11155-11162. doi:10.1073/ pnas. 1004812107

Godfray HCJ, Beddington JR, Crute IR, Haddad L, Lawrence D, Muir JF, Pretty J, Robinson S, Thomas SM, Toulmin C (2010) Food security: the challenge of feeding 9 billion people. Science 327:812-818. doi: 10.1126/science. 1185383

Grimes DW, Yamada H, Dickens WL (1969) Functions for cotton (Gossypium hirsutum L.) production from irrigation and nitrogen fertilization variables: I. yield and evapotranspiration. Agron J 61: 769. doi:10.1111/j.1439-037X.2009.00411.x

Guidi L, Degl'Innocenti E, Remorini D, Massai R, Tattini M (2008) Interactions of water stress and solar irradiance on the physiology and biochemistry of Ligustrum vulgare. Tree Physiol 28:873-883. doi:10.1093/treephys/28.6.873

Hachez C, Heinen RB, Draye X, Chaumont F (2008) The expression pattern of plasma membrane aquaporins in maize leaf highlights their role in hydraulic regulation. Plant Mol Biol 68:337-353. doi: 10.1007/s11103-008-9373-x

Hamzei J, Soltani J (2012) Deficit irrigation of rapeseed for water-saving: effects on biomass accumulation, light interception and radiation use efficiency under different N rates. Agric Ecosyst Environ 155:153160. doi:10.1016/j.agee.2012.04.003

Higa S, Kobori H, Tsuchikawa S (2013) Mapping of leaf water content using near-infrared hyperspectral imaging. Appl Spectrosc 67: 1302-1307. doi:10.1366/13-07028

Homayounfar M, Lai SH, Zomorodian M, Sepaskhah AR, Ganji A (2014) Optimal crop water allocation in case of drought occurrence, imposing deficit irrigation with proportional cutback constraint. Water Resour Manag 28:3207-3225. doi:10.1007/s11269-0140669-0

Hongbo S, Zongsuo L, Mingan S, Shimeng S, Zanmin H (2005) Investigation on dynamic changes of photosynthetic characteristics of 10 wheat (Triticum aestivum L.) genotypes during two vegetativegrowth stages at water deficits. Colloids Surf B Biointerfaces 43: 221-227. doi:10.1016/j.colsurfb.2005.05.005

Hou X, Li R, Jia Z, Han Q, Wang W, Yang B (2012) Effects of rotational tillage practices on soil properties, winter wheat yields and water-use efficiency in semi-arid areas of north-west China. Field Crops Res 129:7-13. doi:10.1016/j.fcr.2011.12.021

Hu T, Kang S, Li F, Zhang J (2009) Effects of partial root-zone irrigation on the nitrogen absorption and utilization of maize. Agrc Water Manag 96:208-214. doi:10.1016/j.agwat.2008.07.011

Hu T, Yuan L, Wang J, Kang S, Li F (2010) Antioxidation responses of maize roots and leaves to partial root-zone irrigation. Agrc Water Manag 98:164-171. doi:10.1016/j.agwat.2010.06.019

Hu F, Chai Q, Yu A, Yin W, Cui H, Gan Y (2015) Less carbon emissions of wheat-maize intercropping under reduced tillage in arid areas. Agron Sustain Dev 35:701-711. doi:10.1007/s13593-014-0257-y

Hutton RJ, Loveys BR (2011) A partial root zone drying irrigation strategy for citrus - effects on water use efficiency and fruit characteristics. Agrc Water Manag 98:1485-1496. doi:10.1016/j.agwat.2011. 04.010

Iqbal MA, Shen Y, Stricevic R, Pei H, Sun H, Amiri E, Penas A, del Rio S (2014) Evaluation of the FAO AquaCrop model for winter wheat on the North China Plain under deficit irrigation from field experiment to regional yield simulation. Agrc Water Manag 135:61-72. doi:10. 1016/j.agwat.2013.12.012
Jarvis NJ (2011) Simple physics-based models of compensatory plant water uptake: concepts and eco-hydrological consequences. Hydrol Earth Syst Sci 15:3431-3446. doi:10.5194/hess-15-34312011

Kang S, Zhang J (2004) Controlled alternate partial root-zone irrigation: its physiological consequences and impact on water use efficiency. $\mathrm{J}$ Exp Bot 55:2437-2446. doi:10.1093/jxb/erh249

Kang S, Shi W, Zhang J (2000) An improved water-use efficiency for maize grown under regulated deficit irrigation. Field Crops Res 67: 207-214. doi:10.1016/S0378-4290(00)00095-2

Kang S, Hu X, Goodwin I, Jerie P (2002) Soil water distribution, water use, and yield response to partial root zone drying under a shallow groundwater table condition in a pear orchard. Sci Hortic 92:277291. doi:10.1016/S0304-4238(01)00300-4

Kirda C, Topcu S, Kaman H, Ulger AC, Yazici A, Cetin M, Derici MR (2005) Grain yield response and $\mathrm{N}$-fertiliser recovery of maize under deficit irrigation. Field Crops Res 93:132-141. doi:10.1016/j.fcr. 2004.09.015

Kirda C, Topcu S, Cetin M, Dasgan HY, Kaman H, Topaloglu F, Derici MR, Ekici B (2007) Prospects of partial root zone irrigation for increasing irrigation water use efficiency of major crops in the Mediterranean region. Ann Appl Biol 150:281-291. doi:10.1111/j. 1744-7348.2007.00141.x

Kirkham MB (1983) Physical model of water in a split-root system. Plant Soil 75:153-168. doi:10.1007/BF02375562

Küppers M, O’Rourke L, Bockelée-Morvan D, Zakharov V, Lee S, Von Allmen P, Carry B, Teyssier D, Marston A, Müller T, Crovisier J, Barucci MA, Moreno R (2014) Localized sources of water vapour on the dwarf planet (1) Ceres. Nature 505:525-527. doi:10.1038/ nature 12918

Kurz M, Buren AY, Seip B, Lindow SE, Gross H (2010) Genome-driven investigation of compatible solute biosynthesis pathways of pseudomonas syringae pv. syringae and their contribution to water stress tolerance. Appl Environ Microbiol 76:5452-5462. doi:10.1128/ AEM.00686-10

Kușçu H, Turhan A, Demir AO (2014) The response of processing tomato to deficit irrigation at various phenological stages in a sub-humid environment. Agrc Water Manag 133:92-103. doi:10.1016/j.agwat. 2013.11.008

Li H, Lascano RJ (2011) Deficit irrigation for enhancing sustainable water use: comparison of cotton nitrogen uptake and prediction of lint yield in a multivariate autoregressive state-space model. Environ Exp Bot 71:224-231. doi:10.1016/j.envexpbot.2010.12.007

Li F, Liang J, Kang S, Zhang J (2007) Benefits of alternate partial rootzone irrigation on growth, water and nitrogen use efficiencies modified by fertilization and soil water status in maize. Plant Soil 295: 279-291. doi:10.1007/s11104-007-9283-8

Li F, Wei C, Zhang F, Zhang J, Nong M, Kang S (2010a) Water-use efficiency and physiological responses of maize under partial rootzone irrigation. Agrc Water Manag 97:1156-1164. doi:10.1016/j. agwat.2010.01.024

Li F, Yu J, Nong M, Kang S, Zhang J (2010b) Partial root-zone irrigation enhanced soil enzyme activities and water use of maize under different ratios of inorganic to organic nitrogen fertilizers. Agrc Water Manag 97:231-239. doi:10.1016/j.agwat.2009.09.014

Li CX, Zhou XG, Sun JS, Wang HZ, Gao Y (2013) Dynamics of root water uptake and water use efficiency under alternate partial rootzone irrigation. Desalin Water Treat. doi:10.1080/19443994.2013. 822647

Liang H, Li F, Nong M (2013) Effects of alternate partial root-zone irrigation on yield and water use of sticky maize with fertigation. Agrc Water Manag 116:242-247. doi:10.1016/j.agwat.2012.08.003

Liu YH (2006) The Chinese Ministry of Science and Technology of Rural and Social Development Division. In: The development strategies on water-saving agriculture in China. Chinese Agricultural Science and Technology Press, Beijing 
Liu Z, Dickmann DI (1996) Effects of water and nitrogen interaction on net photosynthesis, stomatal conductance, and water-use efficiency in two hybrid poplar clones. Physiol Plant 97:507-512. doi:10.1034/ j.1399-3054.1996.970313.x

Liu LX, Xu SM, Woo KC (2004) Deficit irrigation effects on photosynthesis and the xanthophyll cycle in the tropical tree species Acacia auriculiformis in North Australia. N Z J Bot 42:949-957. doi:10. 1080/0028825X.2004.9512941

Liu F, Shahnazari A, Andersen MN, Jacobsen SE, Jensen CR (2006a) Effects of deficit irrigation (DI) and partial root drying (PRD) on gas exchange, biomass partitioning, and water use efficiency in potato. Sci Hortic 109:113-117. doi:10.1016/j.scienta.2006.04.004

Liu F, Shahnazari A, Andersen MN, Jacobsen SE, Jensen CR (2006b) Physiological responses of potato (Solanum tuberosum L.) to partial root-zone drying: ABA signalling, leaf gas exchange, and water use efficiency. J Exp Bot 57:3727-3735. doi:10.1093/jxb/erl131

Liu F, Song R, Zhang X, Shahnazari A, Andersen MN, Plauborg F, Jacobsen SE, Jensen CR (2008) Measurement and modelling of ABA signalling in potato (Solanum tuberosum L.) during partial root-zone drying. Environ Exp Bot 63:385-391. doi:10.1016/j. envexpbot.2007.11.015

Liu L, Gan Y, Bueckert R, Van Rees K (2011) Rooting systems of oilseed and pulse crops I: temporal growth patterns across the plant developmental periods. Field Crops Res 122:256-263. doi:10.1016/j.fcr. 2011.04.002

Ma J, Huang GB, Yang DL, Chai Q (2014) Dry matter remobilization and compensatory effects in various internodes of spring wheat under water stress. Crop Sci 54:331-339. doi:10.2135/cropsci2013.03. 0141

Mansouri-Far C, Modarres Sanavy SAM, Saberali SF (2010) Maize yield response to deficit irrigation during low-sensitive growth stages and nitrogen rate under semi-arid climatic conditions. Agrc Water Manag 97:12-22. doi:10.1016/j.agwat.2009.08.003

Mishra M, Kumar U, Prakash V (2013) Influence of salicylic acid pretreatment on water stress and its relationship with antioxidant status in Glycine max. Int J Pharma Bio Sci 4:B81-B97. doi: 10.1.1.405.7109

Naveed M, Mitter B, Reichenauer TG, Wieczorek K, Sessitsch A (2014) Increased drought stress resilience of maize through endophytic colonization by Burkholderia phytofirmans PsJN and Enterobacter sp. FD17. Environ Exp Bot 97:30-39. doi:10.1016/j.envexpbot.2013. 09.014

Nie L, Peng S, Chen M, Shah F, Huang J, Cui K, Xiang J (2012) Aerobic rice for water-saving agriculture. A review. Agron Sustain Dev 32: 411-418. doi:10.1007/s13593-011-0055-8

Parvathi MS, Nataraja KN, Yashoda BK, Ramegowda HV, Mamrutha HM, Rama N (2013) Expression analysis of stress responsive pathway genes linked to drought hardiness in an adapted crop, finger millet (Eleusine coracana). J Plant Biochem Biotechnol 22:193201. doi:10.1007/s13562-012-0135-0

Pérez-Pastor A, Ruiz-Sánchez MC, Domingo R (2014) Effects of timing and intensity of deficit irrigation on vegetative and fruit growth of apricot trees. Agrc Water Manag 134:110-118. doi:10.1016/j.agwat. 2013.12.007

Prudent M, Salon C, Souleimanov A, Emery RJN, Smith DL (2015) Soybean is less impacted by water stress using Bradyrhizobium japonicum and thuricin-17 from Bacillus thuringiensis. Agron Sustain Dev 35:749-757. doi:10.1007/s13593-014-0256-Z

Romero P, Botia P, Garcia F (2004) Effects of regulated deficit irrigation under subsurface drip irrigation conditions on water relations of mature almond trees. Plant Soil 260:155-168. doi:10.1023/ B:PLSO.0000030178.24522.b3

Romero P, Dodd IC, Martinez-Cutillas A (2012) Contrasting physiological effects of partial root zone drying in field-grown grapevine (Vitis vinifera L. cv. Monastrell) according to total soil water availability. J Exp Bot 63:4071-4083. doi:10.1093/jxb/ers088
Romero P, Gil-Muñoz R, del Amor FM, Valdés E, Fernández JI, Martinez-Cutillas A (2013) Regulated deficit irrigation based upon optimum water status improves phenolic composition in Monastrell grapes and wines. Agrc Water Manag 121:85-101. doi:10.1016/j. agwat.2013.01.007

Sajedi N, Madani H, Naderi A (2011) Effect of microelements and selenium on superoxide dismutase enzyme, malondialdehyde activity and grain yield maize (Zea mays L.) under water deficit stress. Notulae Botanicae Horti Agrobotanici Cluj-Napoca 39:153-159

Salar MR, Esehaghbeygi A, Hemmat A (2013) Soil loosening characteristics of a dual bent blade subsurface tillage implement. Soil Till Res 134:17-24. doi:10.1016/j.still.2013.07.005

Samperio A, Prieto MH, Blanco-Cipollone F, Vivas A, Moñino MJ (2015) Effects of post-harvest deficit irrigation in 'Red Beaut' Japanese plum: tree water status, vegetative growth, fruit yield, quality and economic return. Agrc Water Manag 150:92-102. doi:10. 1016/j.agwat.2014.12.006

Savić S, Stikić R, Radović BV, Bogičević B, Jovanović Z, Šukalović VHT (2008) Comparative effects of regulated deficit irrigation (RDI) and partial root-zone drying (PRD) on growth and cell wall peroxidase activity in tomato fruits. Sci Hortic 117:15-20. doi:10. 1016/j.scienta.2008.03.009

Schiermeier Q (2014) The parched planet: water on tap. Nature 510:326328. doi:10.1038/510326a

Schreiner RP, Tarara JM, Smithyman RP (2007) Deficit irrigation promotes arbuscular colonization of fine roots by mycorrhizal fungi in grapevines (Vitis vinifera L.) in an arid climate. Mycorrhiza 17:551562. doi:10.1007/s00572-007-0128-3

Schroeder JI, Kwak JM, Allen GJ (2001) Guard cell abscisic acid signalling and engineering drought hardiness in plants. Nature 410:327330. doi:10.1038/35066500

Sezen SM, Yazar A, Tekin S (2011) Effects of partial root zone drying and deficit irrigation on yield and oil quality of sunflower in a Mediterranean environment. Irrig Drain 60:499-508. doi:10.1002/ ird.607

Shabani A, Sepaskhah AR, Kamgar-Haghighi AA (2013) Growth and physiologic response of rapeseed (Brassica napus L.) to deficit irrigation, water salinity and planting method. Int J Plant Prod 7:569596

Shahnazari A, Liu F, Andersen MN, Jacobsen SE, Jensen CR (2007) Effects of partial root-zone drying on yield, tuber size and water use efficiency in potato under field conditions. Field Crops Res 100:117-124. doi:10.1016/j.fcr.2006.05.010

Siddique KHM, Bramley H (2014) Water deficits: development. Encyclop Natural Res 1-4. doi:10.1081/E-ENRL-120049220

Simsek M, Comlekcioglu N, Ozturk I (2011) Responses of 'Pacific

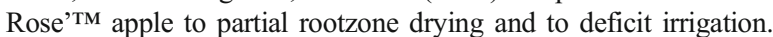
Afr J Biotechnol 10:4057-4064

Sivakumar B (2011) Water crisis: from conflict to cooperation-an overview. Hydrol Sci J 56:531-552. doi:10.1080/02626667.2011. 580747

Sobeih WY, Dodd IC, Bacon MA, Grierson D, Davies WJ (2004) Longdistance signals regulating stomatal conductance and leaf growth in tomato (Lycopersicon esculentum) plants subjected to partial rootzone drying. J Exp Bot 55:2353-2363. doi:10.1093/jxb/erh204

Sofo A, Dichio B, Xiloyannis C, Masia A (2004) Effects of different irradiance levels on some antioxidant enzymes and on malondialdehyde content during rewatering in olive tree. Plant Sci 166:293-302. doi:10.1016/j.plantsci.2003.09.018

Sperry JS, Saliendra NZ, Pockman WT, Cochard H, Cruiziat P, Davis SD, Ewers FW, Tyree MT (1996) New evidence for large negative xylem pressures and their measurement by the pressure chamber method. Plant Cell Environ 19:427-436. doi:10.1111/j.1365-3040.1996. tb00334.x

Sun H, Shen Y, Yu Q, Flerchinger GN, Zhang Y, Liu C, Zhang X (2010) Effect of precipitation change on water balance and WUE of the 
winter wheat-summer maize rotation in the North China Plain. Agrc Water Manag 97:1139-1145. doi:10.1016/j.agwat.2009.06.004

Sun J, Gu J, Zeng J, Han S, Song A, Chen F, Fang W, Jiang J, Chen S (2013a) Changes in leaf morphology, antioxidant activity and photosynthesis capacity in two different drought-tolerant cultivars of chrysanthemum during and after water stress. Sci Hortic 161:249 258. doi:10.1016/j.scienta.2013.07.015

Sun Y, Feng H, Liu F (2013b) Comparative effect of partial root-zone drying and deficit irrigation on incidence of blossom-end rot in tomato under varied calcium rates. J Exp Bot 64:2107-2116. doi: 10.1093/jxb/ert067

Tahkokorpi M, Taulavuori K, Laine K, Taulavuori E (2007) After-effects of drought-related winter stress in previous and current year stems of Vaccinium myrtillus L. Environ Exp Bot 61:85-93. doi:10.1016/j. envexpbot.2007.03.003

Trost B, Prochnow A, Drastig K, Meyer-Aurich A, Ellmer F, Baumecker $M$ (2013) Irrigation, soil organic carbon and $\mathrm{N}_{2} \mathrm{O}$ emissions. A review. Agron Sustain Dev 33:733-749. doi:10.1007/s13593-0130134-0

Ullah S, Skidmore AK, Groen TA, Schlerf M (2013) Evaluation of three proposed indices for the retrieval of leaf water content from the midwave infrared (2-6 $\mu \mathrm{m})$ spectra. Agr Forest Meteorol 171-172:6571. doi:10.1016/j.agrformet.2012.11.014

Ünlü M, Kanber R, Koç DL, Tekin S, Kapur B (2011) Effects of deficit irrigation on the yield and yield components of drip irrigated cotton in a Mediterranean environment. Agrc Water Manag 98:597-605. doi:10.1016/j.agwat.2010.10.020

Upadhyaya A, Cladwell CR (1993) Applicability of the triphenyl tetrazolium chloride reduction viability assay to the measurement of oxidative damage to cucumber cotyledons by bisulfite. Environ Exp Bot 33:357-365. doi:10.1016/0098-8472(93)90037-G

Van Hooijdonk BM, Dorji K, Behboudian MH (2004) Responses of 'Pacific Rose'TM apple to partial rootzone drying and to deficit irrigation. Eur J Hortic Sci 69:104-110

Vandoorne B, Mathieu AS, Van Den Ende W, Vergauwen R, Périlleux C, Javaux M, Lutts S (2012) Water stress drastically reduces root growth and inulin yield in Cichorium intybus (var. sativum) independently of photosynthesis. J Exp Bot 63:4359-4373. doi:10.1093/ jxb/ers095

Wang J, de Kroon H, Wang L, de Caluwe H, Bögemann GM, van der Weerden GM, Kang S, Smits AJM (2009) Root foraging and yield components underlying limited effects of partial root-zone drying on oilseed rape, a crop with an indeterminate growth habit. Plant Soil 323:163-176. doi:10.1007/ s11104-009-9922-3

Wang Y, Liu F, Andersen MN, Jensen CR (2010a) Improved plant nitrogen nutrition contributes to higher water use efficiency in tomatoes under alternate partial root-zone irrigation. Funct Plant Biol 37:175182. doi:10.1071/FP09181

Wang Y, Liu F, de Neergaard A, Jensen LS, Luxhøi J, Jensen CR (2010b) Alternate partial root-zone irrigation induced dry/wet cycles of soils stimulate $\mathrm{N}$ mineralization and improve $\mathrm{N}$ nutrition in tomatoes. Plant Soil 337:167-177. doi:10.1007/s11104-010-0513-0

Wang Z, Kang S, Jensen CR, Liu F (2012a) Alternate partial root-zone irrigation reduces bundle-sheath cell leakage to $\mathrm{CO} 2$ and enhances photosynthetic capacity in maize leaves. J Exp Bot 63:1145-1153. doi:10.1093/jxb/err331

Wang Z, Liu F, Kang S, Jensen CR (2012b) Alternate partial root-zone drying irrigation improves nitrogen nutrition in maize (Zea mays L.) leaves. Environ Exp Bot 75:36-40. doi:10.1016/j.envexpbot.2011. 08.015

Wang Y, Liu F, Jensen LS, de Neergaard A, Jensen CR (2013) Alternate partial root-zone irrigation improves fertilizer-N use efficiency in tomatoes. Irrig Sci 31:589-598. doi:10.1007/ s00271-012-0335-3
Webber HA, Madramootoo CA, Bourgault M, Horst MG, Stulina G, Smith DL (2006) Water use efficiency of common bean and green gram grown using alternate furrow and deficit irrigation. Agrc Water Manag 86:259-268. doi:10.1016/j.agwat.2006.05.012

Xie K, Wang XX, Zhang R, Gong X, Zhang S, Mares V, Gavilán C, Posadas A, Quiroz R (2012) Partial root-zone drying irrigation and water utilization efficiency by the potato crop in semi-arid regions in China. Sci Hortic 134:20-25. doi:10.1016/j.scienta.2011.11.034

$\mathrm{Xu} \mathrm{HL}$, Qin F, Xu R, Wang F, Li F (2009a) Applications of xerophytophysiology in plant production-sorghum plants improved by exposing the mesocotyl as stimulus. J Food Agric Environ 7:603-610

Xu S, Ding H, Su F, Zhang A, Jiang M (2009b) Involvement of protein phosphorylation in water stress-induced antioxidant defense in maize leaves. J Integr Plant Biol 51:654-662. doi:10.1111/j.17447909.2009.00844.x

$\mathrm{Xu}$ HL, Qin F, Xu Q, Tan J, Liu G (2011a) Applications of xerophytophysiology in plant production - the potato crop improved by partial root zone drying of early season but not whole season. Sci Hortic 129:528-534. doi:10.1016/j. scienta.2011.04.016

Xu HL, Qin FF, Xu QC, Xu RY, Wang TY, Wang R (2011b) Applications of xerophytophysiology in plant production: sub-irrigation improves tomato fruit yield and quality. J Food Agric Environ 9:256-263

Xu HL, Xu Q, Li F, Feng Y, Qin F, Fang W (2012) Applications of xerophytophysiology in plant production-LED blue light as a stimulus improved the tomato crop. Scie Hortic 148:190-196. doi:10. 1016/j.scienta.2012.06.044

Xue Q, Zhu Z, Musick JT, Stewart BA, Dusek DA (2006) Physiological mechanisms contributing to the increased water-use efficiency in winter wheat under deficit irrigation. J Plant Physiol 163:154-164. doi:10.1016/j.jplph.2005.04.026

Yactayo W, Ramírez DA, Gutiérrez R, Mares V, Posadas A, Quiroz R (2013) Effect of partial root-zone drying irrigation timing on potato tuber yield and water use efficiency. Agrc Water Manag 123:65-70. doi:10.1016/j.agwat.2013.03.009

Yan F, Sun Y, Song F, Liu F (2012) Differential responses of stomatal morphology to partial root-zone drying and deficit irrigation in potato leaves under varied nitrogen rates. Sci Hortic 145:76-83. doi: 10.1016/j.scienta.2012.07.026

Yang L, Qu H, Zhang Y, Li F (2012a) Effects of partial root-zone irrigation on physiology, fruit yield and quality and water use efficiency of tomato under different calcium levels. Agrc Water Manag 104:8994. doi:10.1016/j.agwat.2011.12.001

Yang QL, Zhang FC, Liu XG, Ge ZY (2012b) Effects of controlled alternate partial root-zone drip irrigation on apple seedling morphological characteristics and root hydraulic conductivity. Chin J Appl Eco 23:1233-1239

Yi QX, Bao AM, Wang Q, Zhao J (2013) Estimation of leaf water content in cotton by means of hyperspectral indices. Comput Electron Agric 90:144-151. doi:10.1016/j.compag.2012.09.011

Yin W, Yu A, Chai Q, Hu F, Feng F, Gan Y (2015) Wheat and maize relay-planting with straw covering increases water use efficiency up to $46 \%$. Agron Sustain Dev 35:815-825. doi:10.1007/s13593-0150286-1

Yuan L, Zhang Z, Cao X, Zhu S, Zhang X, Wu L (2014) Responses of rice production, milled rice quality and soil properties to various nitrogen inputs and rice straw incorporation under continuous plastic film mulching cultivation. Field Crops Res 155:164-171. doi:10. 1016/j.fcr.2013.09.009

Zegbe-Domínguez JA, Behboudian MH, Lang A, Clothier BE (2003) Deficit irrigation and partial rootzone drying maintain fruit dry mass and enhance fruit quality in 'Petopride' processing tomato (Lycopersicon esculentum, Mill.). Sci Hortic 98:505-510. doi:10. 1016/S0304-4238(03)00036-0 
Zhang L, Zhou Z, Zhang G, Meng Y, Chen B, Wang Y (2012) Monitoring the leaf water content and specific leaf weight of cotton (Gossypium hirsutum L.) in saline soil using leaf spectral reflectance. Eur J Agron 41:103-117. doi:10.1016/j.eja.2012.04.003

Zhu Y, Gong H (2014) Beneficial effects of silicon on salt and drought tolerance in plants. Agron Sustain Dev 34:455-472. doi:10.1007/ s13593-013-0194-1
Zhuang Y, Ren G, Yue G, Li Z, Qu X, Hou G, Zhu Y, Zhang J (2007) Effects of water-deficit stress on the transcriptomes of developing immature ear and tassel in maize. Plant Cell Rep 26:2137-2147. doi: 10.1007/s00299-007-0419-3 